14 | Sublethal effects of the Water -Soluble Fractions of Virgin Diesel Oil on some Physiological ...
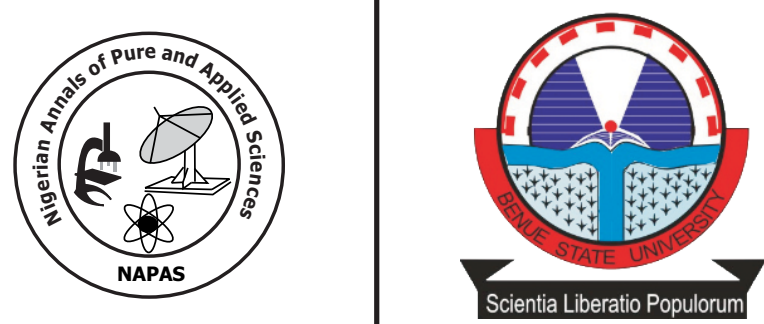

pp $14-32$

\title{
Sublethal effects of the Water -Soluble Fractions of Virgin Diesel Oil on some Physiological Parameters of Clarias Gariepinus Juveniles.
}

Lemuel, A.S., Banyigyi, A.H., Makpo, J.K., Abdulmalik, A.A, and Andrew, N.C. Department of Zoology, Nasarawa State University, Keffi Corresponding Authors: slemuel3@gmail.com

\begin{abstract}
This study was undertaken to evaluate the sublethal effects of the water-soluble fractions of virgin diesel oil on some physiological parameters of $C$. gariepinus juveniles. The mean weight of $C$.gariepinus Juveniles weight of $1.61 \pm 1.86 \mathrm{~g}$, total length of $9.5 \pm 10.5 \mathrm{~cm}$ and standard length of $11.0 \pm 12.5 \mathrm{~cm}$ were exposed to sublethal concentrations of $0.58 \mathrm{ml} / \mathrm{L}, 0.29 \mathrm{ml} / \mathrm{L}, 0.14 \mathrm{ml} / \mathrm{L}, 0.07 \mathrm{ml} / \mathrm{L}, 0.04 \mathrm{ml} / \mathrm{L}$ and control $0.00 \mathrm{ml} / \mathrm{L}$. There were significant differences at $(\mathrm{P}<0.05)$ on the different levels of sublethal concentrations. The tissues include; gills, liver and intestine. The alterations considered include; the gills; inflammation, hyperplasia, fusion, lamella aneurism, epithelial lifting, abrasion and necrosis, in the liver, there was lesions, and inflammation, and also alterations of the intestine were mainly sloughing of the intestinal villi and intestinal mucosa. It was concluded that contamination of water-soluble fractions of virgin diesel oil in any water body or aquatic environment can induce several histopathological alterations in the tissues of Clarias gariepinus juvenile.
\end{abstract}

Key words: Virgin Diesel Oil, Clarias gariepinus, gill, liver and intestine. 


\section{Introduction}

Ecotoxicology is the study of the impact of environmental contaminants on ecosystems. Understanding the effect of toxicants on fish supports the larger ecotoxicological goal of comprehending the action of ecotoxicants on fish population (Bols et al. 2001). Ecotoxicants are diverse groups of substrates that have two general properties: they are dispersed into the environment, and they have the potential to impact on the ecosystem and animals at relatively low concentration (Connell et al. 1999). Heavy metals are the major chemical substrates that contaminate the ecosystems (Bols et al. 2001). In addition, relatively recently, a new form of Ag (Silver) metal has been engineered comprising of Ag nanoparticles (Ag NPs) that can have novel and size-related physicochemical properties differing significantly from those from larger particles (Fabrega et al. 2011). Ag NPs are widely used in medicine, cosmetics, environmental remediation or electronic devices (Fabrega et al. 2011) and have distinctive physicochemical properties, including surface- enhanced Raman scattering, high electrical and thermal conductivity.. Ag can also cause tissue damage and accumulate in the liver tissue affecting the ability of fish to cope with low oxygen levels and inducing oxidative stress (Bilberg et al. 2010a, b;).

Diesel fuel is heavier and oilier than other petroleum oils. It is obtained from distillation or refining of crude oil i.e., from petroleum products. Diesel requires less maintenance and generates energy more efficiently with less Carbon (iv) oxide $\left(\mathrm{CO}_{2)}\right.$ emission, but when uncontrolled, emits harmful particulate matter, nitrogen oxides and a variety of carcinogenic substances examples, Nickel, Cadmium, Radon, Benzene etc. In spite of the lower $\mathrm{CO}_{2}$ emissions and economically profitable, today's diesels are more harmful to human health as well as aquatic life. Petroleum discharge containing hydrocarbons is considered a worldwide problem (Pauluis, 1979; Solangi and Overstreet, 1982). Crude oil pollution is a common occurrence the world over, particularly in nations whose economies are largely dependent on the oil industry.

Nigeria, for example, is a country where petroleum has remained the most important source of revenue generation for the past four decades. Oil exploration and exploitation at the onshore and offshore are carried out at the Niger Delta areas, producing more than $90 \%$ of crude oil in Nigeria and thus hosting most of the terminals of oil (Wegwu and Omoedu, 2010). Other environmental degredation problems in Nigeria include desert exploring or encroachment, wide life depletion, over flooding, land, water and air pollution few among others. The exploitation of oil in the Niger Delta region, engineering failures, hose failures, shipping activities, accident through loading, rupture of flow lines and channel pipe vanderlization has brought to open or bear oil spillage and it's much numerous effects.

This study will help to create public awareness and understanding of diesel oil spill problems to the environment. It will also highlight the extent of the effect of unused diesel oil spillage and point out other relevant issues deserving the attention of the relevant authorities to enact and implement laws, policies and enforcement measures within the existing production regions or users country wide. Hence, this study or research tries to find out effects of the water soluble fractions of virgin diesel oil on some physiological parameters of Clarias gariepinus juveniles in an enclosed system.

\section{Materials and Methods}

The experiment was conducted using plastic bowls in the Zoology Laboratory of the Department of Zoology, Faculty of Natural and Applied Sciences; Nasarawa State University Keffi. Each Plastic bowl six (6) had a dimension of $60 \mathrm{~cm} \times 30 \mathrm{~cm}$, filled with 15 liters of dechlorinated tap water for the study. The sublethal concentrations had five (5) treatments and with one (1) control, the system had aerator model $\mathrm{SOBO}^{\mathrm{R}}$ air pump SB-548A.The water parameters determined include temperature, dissolved oxygen, $\mathrm{pH}$, electrical conductivity and total dissolved solute (TDS). These physicochemical parameters of water were measured using a multi-parameter EXTECH $^{\mathrm{R}}$ DO600 instrument a portable environmental meter. The experimental records were taken and mean values recorded.

\section{Source of Experimental Fish}

Clarias gariepinus had a total of 240 mixed sex juveniles having mean weight of 
$1.61 \pm 1.86 \mathrm{~g}$, standard length of $9.5 \pm 10.5 \mathrm{~cm}$ and mean total length of $11.0 \pm 12.5 \mathrm{~cm}$ were obtained from Rayuwa Farms Limited at Masaka Karu Local Government Area, about 25 $\mathrm{km}$ from Keffi. The fish were transported in two (2) 50 litres jerricans in the morning to the laboratory. On arrival, the fish were distributed into ten (10) plastic bowls, each fresh bowl contain twenty (20) fish for acclimatization. Fresh water was gradually introduced to the fish in the experimental container in order not to give them a great shock. This process is known as tempering of fish.

From the second day of the arrival of the fish, they were fed with comercial Sersirgwe feeds for Aquaculture with pellets range of $3 \mathrm{~mm}$ starter with the following composition protein $43.00 \%$, moisture $8.00 \%$, fat $13.50 \%$, crude fibre $5.00 \%$, calcium $1.80 \%$ and Ash $10.00 \%$ fed to satiation morning 8:00am and evening 6:00pm photoperiod.

Changing of water commenced after every three (3) days until they are used to the new environment for fourteen (14) days period before commencement of the research.

\section{Source of the Virgin Diesel Oil and Preparation for Bioassay}

The virgin diesel oil used for this study was obtained from Silveray Resources Limited Filling Station, beside Antau Bridge Keffi. The water-soluble fractions of virgin diesel oil was prepared by placing one part oil over nine parts of water as described by (Anderson et al.,1974). The mixture was poured into a glass aspirator and placed on a hot plate with a magnetic stirrer of $2.5 \mathrm{~cm}$ length and 0.9 diameter, which is a device that employs a rotating magnetic field to cause a stir bar (or flea) immersed in liquid to spin very quickly, thus stirring it. It was allowed to boiled and stirred for 6-7 hours and then poured into a bigger containers of 50 litres and it was then allowed to cool for 48 hours before decantation (Afolabi et al.,1985;Dede and Kaglo., 2001). It was filtered with a fine piece of white cloth two times to obtain the pure watersoluble fraction of it components free from floating debris of oil. This process was repeated several times until sufficient quantities of the water-soluble fraction was obtained to carry out the research.A glass cylinder was used to measure the amount of virgin diesel oil watersoluble fraction required for both the lethal and sub-lethal concentration.

\section{Sub-lethal Test}

The sub-lethal plastic bowl original were five (5) each with it duplicated six (6) and the control one (1) making twelve (12) treatments, and stocking density remain 10 fish per plastic bowl, the treatments were supplied with oxygen using aerator $\mathrm{SOBO}^{\mathrm{R}}$ air pump $\mathrm{SB}$ 548A, and during the sub-lethal test the weight, standard length and the total length were taken after two weeks and the mean recorded. A concentration of $0.58 \mathrm{ml} / \mathrm{L}, 0.29 \mathrm{ml} / \mathrm{L}, 0.14$ $\mathrm{ml} / \mathrm{L}, 0.07 \mathrm{ml} / \mathrm{L}, 0.04 \mathrm{ml} / \mathrm{L}$ and $0.00 \mathrm{ml} / \mathrm{L}$, the concentrations were obtained after series of trials, because the purpose was to exposed them and see the effects and not to kill them. The serial dilution was made in such a way that the preceding concentration was half the succeeding one in descending order according to FAO (2016). The fish were weighed before introduction and time noted. They were fed twice a day between $8.0^{\prime}$ 'clock in the morning and 6.0'clock in the evening as they are fed according to there body weight at $3 \%$ to minimize left over feeds and metabolic waste contamination of the water, the bioassay were renewed after three days, the water parameters were recorded on daily basis and the mean taken. The plastic bowls were covered with fine netting materials to prevent the fish from jumping out throughout the experiment duration.The sub-lethal test lasted for the period of ten(10) weeks and, the exposed and nonexposed fish gills, liver and intestine were collected and analyzed for comparison.

\section{Histological Processing Of Relevant Tissues By Paraffin Wax Method and Haematoxylin and Eosin Staining Technique}

The investigation was done at National Veterinary Resarch institute vom (NVRI). The gills and livers of Clarias gariepinus were used for histological examination using Lorke's method which were harvested and placed in $10 \%$ buffered formol saline to fix for 3 days. These tissues were then processed to produce stained slides which were then read for possible lesions and pathology as described by (Avwioro, 2011 and Choji et al.,2015)

Sections of the tissues were dewaxed and hydrated by passing through xylene grades at descending grades of alcohol $(100 \%, 80 \%$, 
$70 \%$ ) for three minutes each and then into water, stained in Harris' haematoxylin solution for 5 minutes and washed in running water. The tissues were then differentiated in $1 \%$ acid-alcohol and then washed well in water, blued in Scott's tap water substitute for 5 minutes and rinsed briefly in distilled water, counterstained in $1 \%$ aqueous eosin for 2 minutes, washed well in water, dehydrated in descending grades of alcohol, cleared in xylene and mounted in DPX (Destrene, plasticiser and xylene). Sections of the tissues were then placed in slide carriers and placed in an oven at $40{ }^{\circ} \mathrm{C}$ and dried overnight. (Choji et al., 2015)
The tissues were read microscopically under a light microscope at x10 and x40 magnifications.

\section{Statistical Analysis}

Data obtained were subjected to statistical analysis. The statistical difference between the test groups were estimated and the Mean \pm Standard Error was subjected to Analysis of Variance (ANOVA) using statistical programme for social sciences (SPSS) software, version 22.0. The P-value $<0.05$ were considered statistically significant.

\section{RESULTS}

Table 1: Physico-chemical Parameters of Sublethal Treatment.

\begin{tabular}{|c|c|c|c|c|c|c|}
\hline \multirow[b]{2}{*}{ Parameters } & \multirow[b]{2}{*}{0.00} & \multirow[b]{2}{*}{0.58} & \multirow[b]{2}{*}{0.29} & \multicolumn{3}{|c|}{ Concentration (ml/L) } \\
\hline & & & & 0.14 & 0.07 & 0.04 \\
\hline Temperature $\left({ }^{\circ} \mathrm{C}\right)$ & $23.39 \pm 0.47^{\mathrm{a}}$ & $25.67 \pm 0.52^{\mathrm{b}}$ & $24.85 \pm 0.48^{\mathrm{ab}}$ & $24.67 \pm 0.54^{\mathrm{ab}}$ & $23.96 \pm 0.59^{\mathrm{ab}}$ & $24.44 \pm 0.56^{\mathrm{ab}}$ \\
\hline $\mathrm{p}^{\mathrm{H}}$ & $7.13 \pm 0.21^{\mathrm{a}}$ & $6.27 \pm 0.16^{\mathrm{b}}$ & $6.17 \pm 0.25^{\mathrm{b}}$ & $6.21 \pm 0.13^{b}$ & $6.06 \pm 0.242^{b}$ & $5.43 \pm 0.26^{\mathrm{ab}}$ \\
\hline \multirow{2}{*}{$\begin{array}{l}\text { Dissolved Oxygen } \\
(\mathrm{DO})(\mathrm{mg} / \mathrm{L})\end{array}$} & $6.90 \pm 0.24^{b}$ & $2.97 \pm 0.18 \mathrm{a}$ & $3.76 \pm 0.19^{\mathrm{a}}$ & $379 . \pm 0.13^{\mathrm{a}}$ & $5.14 \pm 0.34^{b}$ & $5.21 \pm 0.21^{\mathrm{b}}$ \\
\hline & $98.50 \pm 4.55^{\mathrm{c}}$ & $180.80 \pm 3.10^{\mathrm{a}}$ & $168.20 \pm 2.70^{\mathrm{a}}$ & $148.80 \pm 2.59^{\mathrm{a}}$ & $128.20 \pm 4.13^{\mathrm{b}}$ & $108.20 \pm 5.47^{\mathrm{bc}}$ \\
\hline \multicolumn{7}{|l|}{ Electrical } \\
\hline Conductivity $\mu \mathrm{s} / \mathrm{cm}$ & $108.00 \pm 8.27^{c}$ & c $248.20 \pm 5.50^{\mathrm{a}}$ & $200.30 \pm 2.99^{a}$ & a $180.70 \pm 3.28^{\mathrm{ab}}$ & $148.70 \pm 5.01^{b c}$ & $128.00 \pm 5.00^{c}$ \\
\hline $\begin{array}{l}\text { Total Dissolved solic } \\
\text { (TDS) }(\mathrm{mg} / \mathrm{L})\end{array}$ & & & & & & \\
\hline
\end{tabular}

Means values with the same superscript in the same row are not significantly different $(\mathrm{P}>0.05)$. 
18 | Sublethal effects of the Water -Soluble Fractions of Virgin Diesel Oil on some Physiological ...

Table 2: Growth Performance of Clarias Gariepinus Juveniles Exposed to Sublethal Concentration of Water - Soluble Fraction of Virgin Diesel Oil for Ten (10) Weeks

\begin{tabular}{|c|c|c|c|c|c|c|c|c|c|}
\hline \multirow[b]{2}{*}{$\begin{array}{l}\text { Concentration } \\
(\mathrm{ml} / \mathbf{L})\end{array}$} & \multicolumn{9}{|c|}{ Growth Parameters } \\
\hline & & Initial & 2 & 4 & 6 & 8 & 10 & Gain & $\begin{array}{l}\% \\
\text { Gain }\end{array}$ \\
\hline \multirow[t]{3}{*}{0.00} & Weight & $2.28 \pm 0.04$ & $2.55 \pm 0.44$ & $2.60 \pm 0.06$ & $2.64 \pm 0.06$ & $2.72 \pm 0.07$ & $2.78 \pm 0.07$ & 0.50 & 21.93 \\
\hline & Total length & $12.06 \pm 0.28$ & $15.09 \pm 0.14$ & $15.32 \pm 0.14$ & $15.71 \pm 0.13$ & $16.11 \pm 0.13$ & $16.26 \pm 0.33$ & 4.20 & 34.83 \\
\hline & Standard length & $10.30 \pm 0.02$ & $10.24 \pm 0.25$ & $10.50 \pm 0.25$ & $11.07 \pm 0.24$ & $11.50 \pm 0.22$ & $11.80 \pm 0.22$ & 1.50 & 14.56 \\
\hline \multirow[t]{3}{*}{0.58} & Weight & $2.36 \pm 0.06$ & $2.39 \pm 0.60$ & $2.45 \pm 0.77$ & $2.52 \pm 0.09$ & $2.55 \pm 0.09$ & $2.59 \pm 0.93$ & 0.23 & 9.75 \\
\hline & Total length & $11.29 \pm 0.24$ & $11.94 \pm 0.33$ & $12.19 \pm 0.33$ & $12.47 \pm 0.32$ & $12.51 \pm 0.30$ & $12.89 \pm 0.28$ & 1.60 & 14.17 \\
\hline & Standard length & $9.52 \pm 0.26$ & $9.36 \pm 0.27$ & $9.68 \pm 0.26$ & $10.20 \pm 0.25$ & $10.66 \pm 0.23$ & $11.33 \pm 0.20$ & 3.60 & 37.82 \\
\hline \multirow[t]{3}{*}{0.29} & Weight & $2.44 \pm 0.06$ & $2.30 \pm 0.03$ & $2.36 \pm 0.03$ & $2.40 \pm 0.03$ & $3.63 \pm 1.18$ & $2.50 \pm 0.30$ & 0.06 & 2.46 \\
\hline & Total length & $11.29 \pm 0.33$ & $12.22 \pm 0.37$ & $12.66 \pm 0.37$ & $12.98 \pm 0.36$ & $13.37 \pm 0.36$ & $13.00 \pm 0.36$ & 1.71 & 13.15 \\
\hline & Standard length & $9.90 \pm 0.32$ & $9.85 \pm 0.35$ & $10.50 \pm 0.27$ & $10.97 \pm 0.27$ & $11.45 \pm 0.24$ & $11.90 \pm 0.24$ & 2.00 & 20.20 \\
\hline \multirow[t]{3}{*}{0.14} & Weight & $2.29 \pm 0.04$ & $2.59 \pm 0.02$ & $2.63 \pm 0.02$ & $2.67 \pm 0.02$ & $2.70 \pm 0.02$ & $2.75 \pm 0.26$ & 0.46 & 20.09 \\
\hline & Total length & $13.00 \pm 5.17$ & $14.49 \pm 0.22$ & $14.86 \pm 0.21$ & $15.24 \pm 0.20$ & $15.55 \pm 0.19$ & $15.00 \pm 0.19$ & 2.00 & 9.04 \\
\hline & Standard length & $9.32 \pm 0.30$ & $10.47 \pm 0.35$ & $10.76 \pm 0.34$ & $11.22 \pm 0.33$ & $11.59 \pm 0.34$ & $12.03 \pm 0.33$ & 2.71 & 29.08 \\
\hline \multirow[t]{3}{*}{0.07} & Weight & $2.29 \pm 0.05$ & $2.60 \pm 0.02$ & $2.65 \pm 0.02$ & $2.71 \pm 0.01$ & $2.76 \pm 0.01$ & $2.82 \pm 0.01$ & 0.53 & 23.14 \\
\hline & Total length & $12.28 \pm 0.33$ & $14.33 \pm 0.29$ & $14.78 \pm 0.29$ & $15.22 \pm 0.28$ & $15.64 \pm 0.27$ & $16.04 \pm 0.27$ & 3.76 & 30.62 \\
\hline & Standard length & $9.28 \pm 0.30$ & $11.53 \pm 0.10$ & $11.89 \pm 0.19$ & $12.25 \pm 0.19$ & $12.62 \pm 0.21$ & $13.02 \pm 0.20$ & 3.74 & 40.30 \\
\hline \multirow[t]{3}{*}{0.04} & Weight & $2.29 \pm 0.05$ & $2.53 \pm 0.05$ & $2.57 \pm 0.05$ & $2.65 \pm 0.040$ & $2.76 \pm 0.07$ & $2.80 \pm 0.07$ & 0.51 & 22.27 \\
\hline & Total length & $12.71 \pm 0.28$ & $14.90 \pm 0.18$ & $15.36 \pm 0.17$ & $15.72 \pm 0.16$ & $16.16 \pm 1.50$ & $16.50 \pm 0.14$ & 3.79 & 29.82 \\
\hline & Standard length & $10.29 \pm 0.28$ & $11.27 \pm 0.10$ & $11.67 \pm 0.10$ & $12.05 \pm 0.19$ & $12.45 \pm 0.19$ & $12.84 \pm 0.17$ & 2.55 & 24.78 \\
\hline
\end{tabular}

Means values that are not the same on a roware not significantly different $(\mathrm{P}>0.05)$

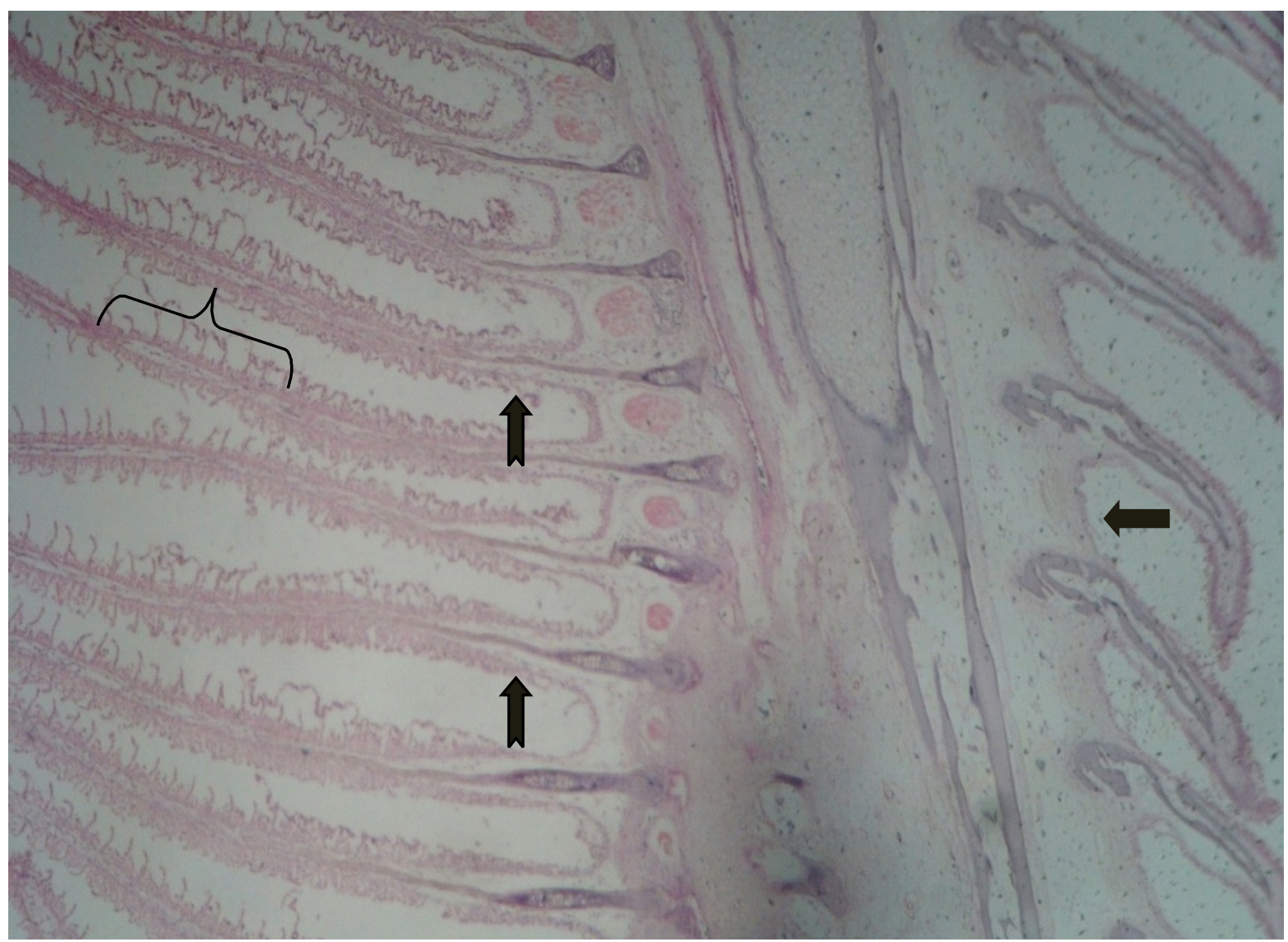

PLATE 1: Normal fish gills.

Normal Fish Gills with filament ( 1 ) gill arch ( Magnification x100 


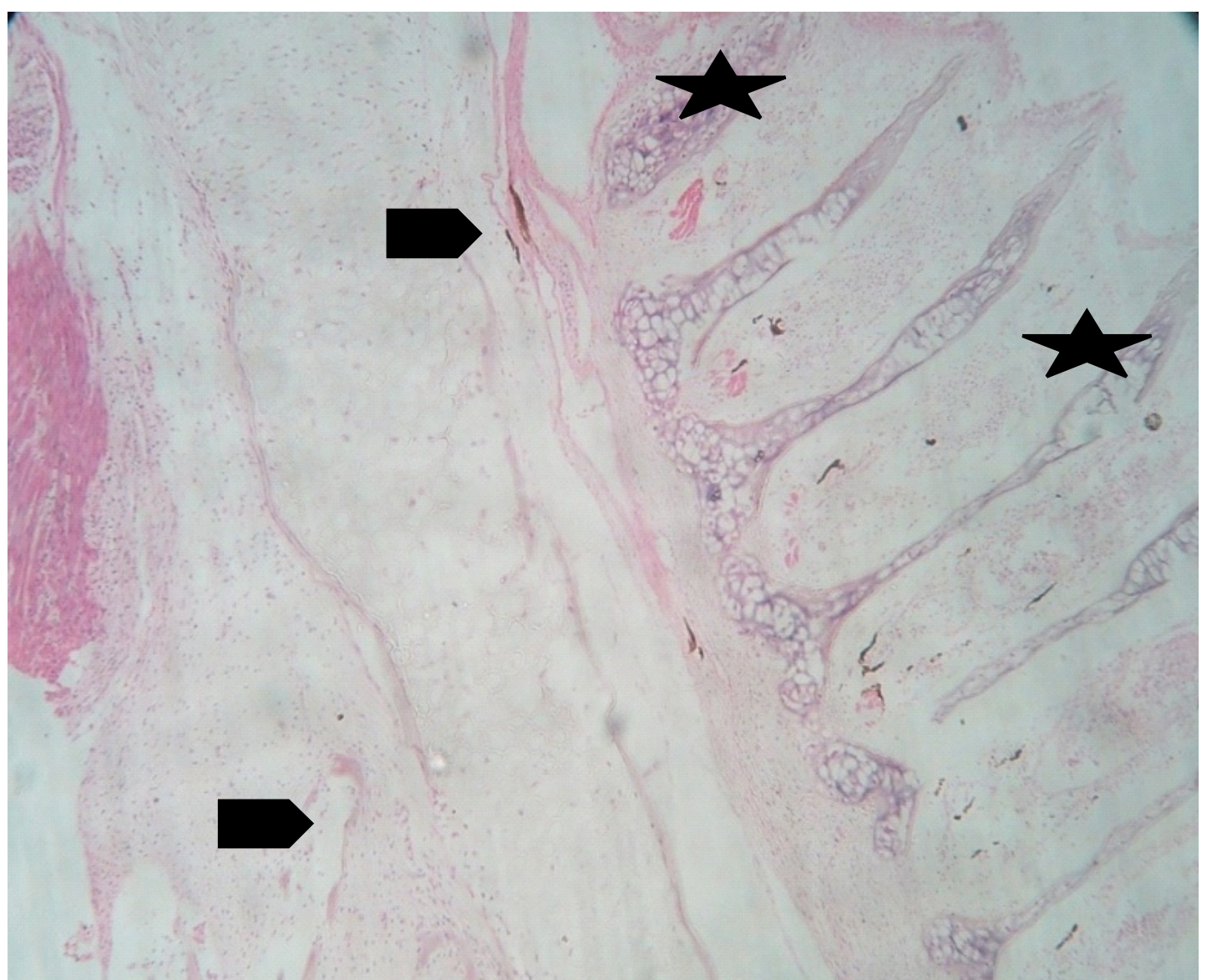

PLATE 2: Fish gills with necrosis and hyperplasia.

Fish Gills with necrosis, $(\rightarrow)$ ) hyperplasia $(\rightarrow)$, at $0.58 \mathrm{ml} / \mathrm{L}$ concentration Magnification x100.

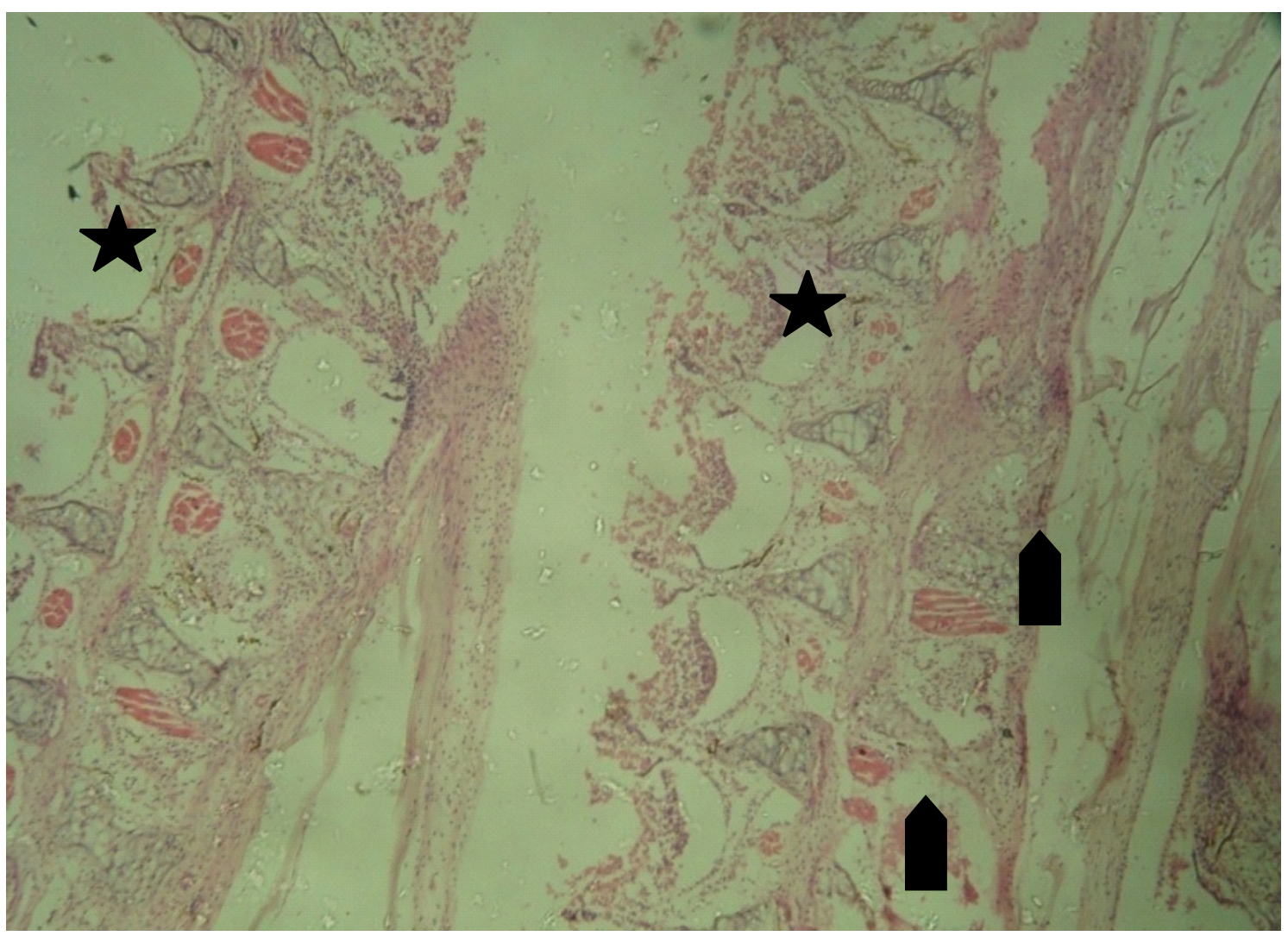

PLATE 3 :Fish gills with epithelia lifting and fusion.

Fish Gills with epithelia lifting ( $)$ and fusion $(\widehat{\sim})$ at $0.29 \mathrm{ml} / \mathrm{L}$ consentration. Magnification $\mathrm{x} 10$ 
20 | Sublethal effects of the Water -Soluble Fractions of Virgin Diesel Oil on some Physiological ...

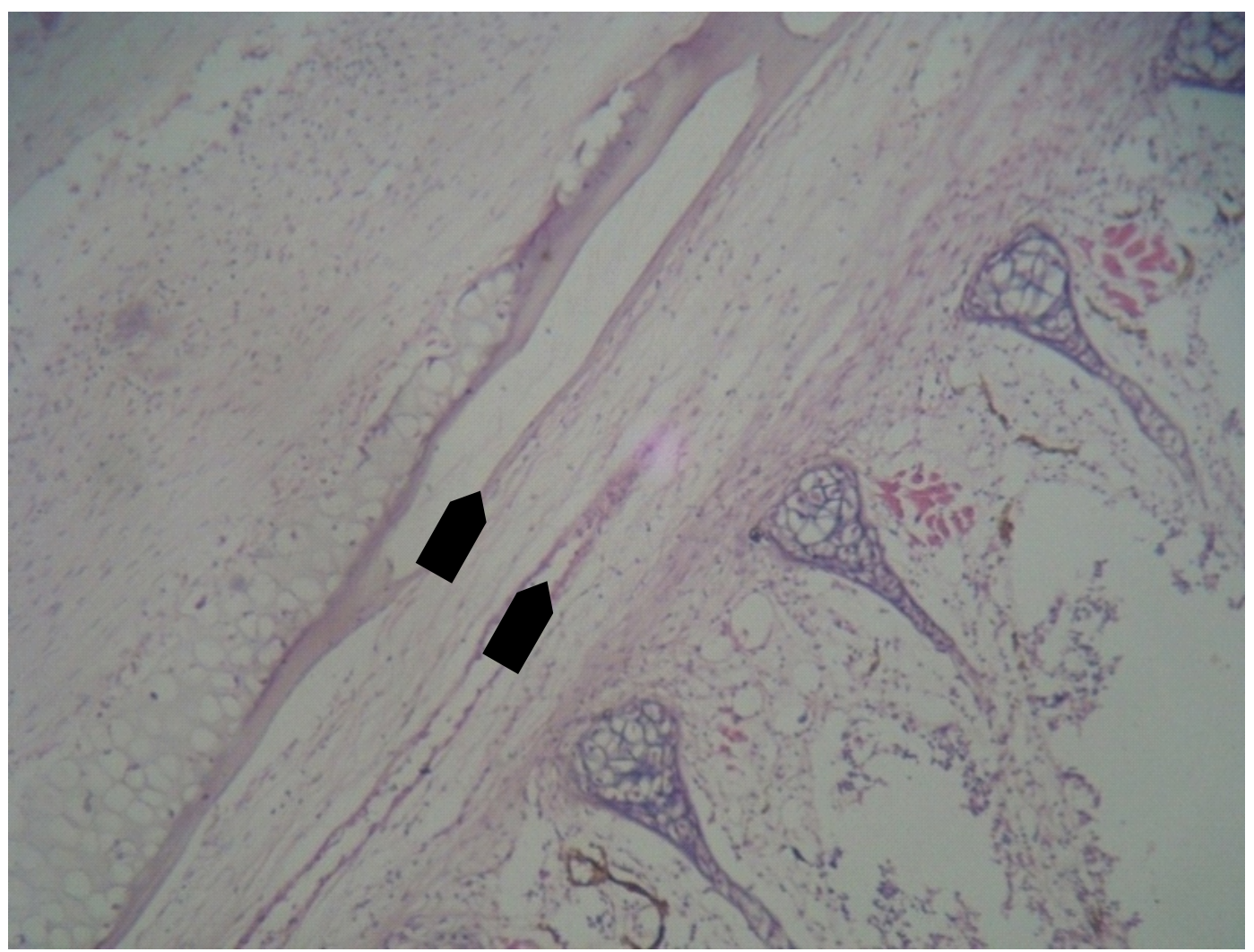

PLATE 4 :Fish gills with lamella aneurism.

Fish Gills with Lamela aneurism ( ) a kind of excessive localized swelling at $0.014 \mathrm{ml} / \mathrm{L}$. Magnification x10

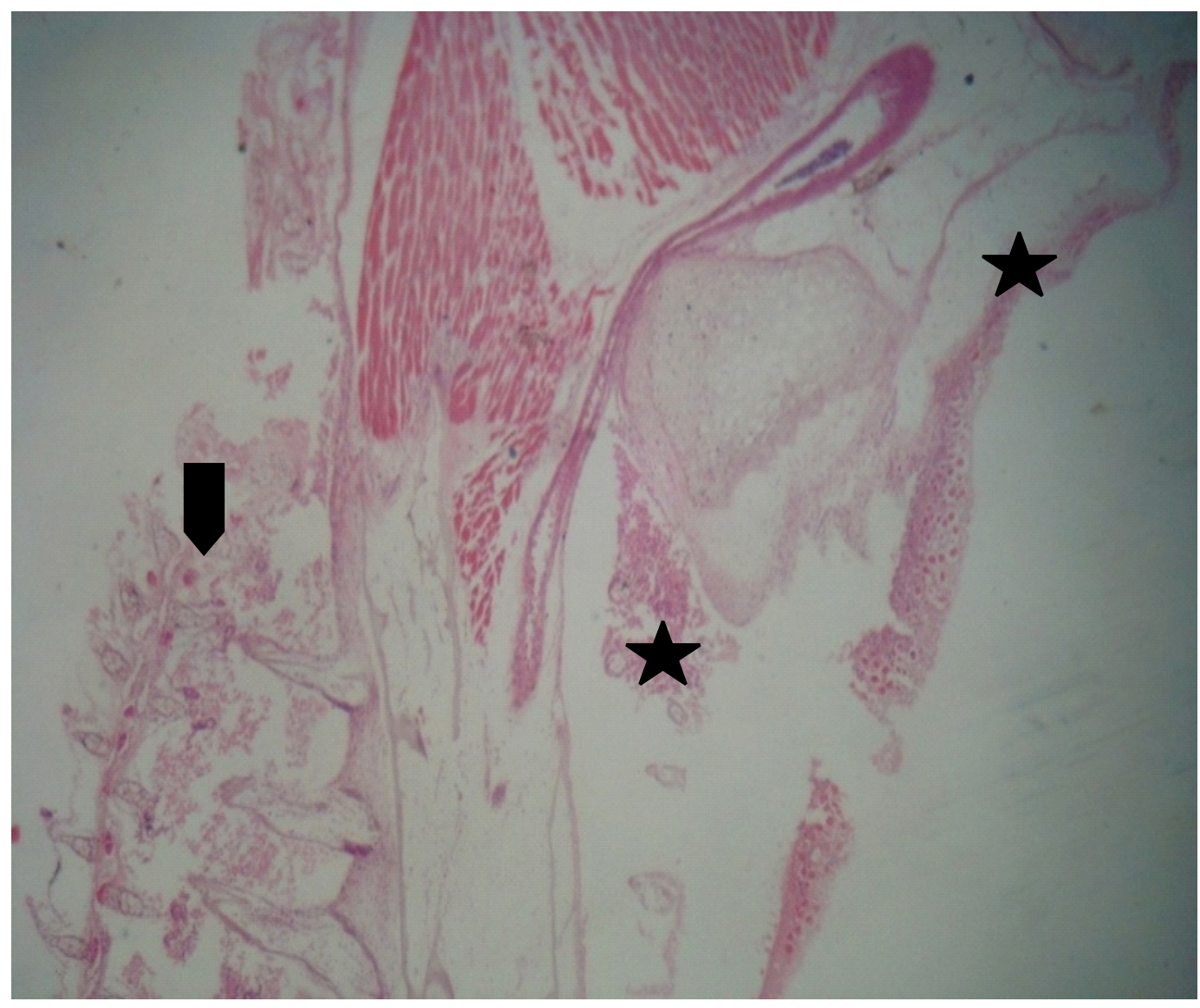

PLATE 5 :Fish gills with inflammation and lesion Fish Gills at $0.07 \mathrm{ml} / \mathrm{L}$ with inflammation $(y)$ and lesions ( ) Magnification x10 


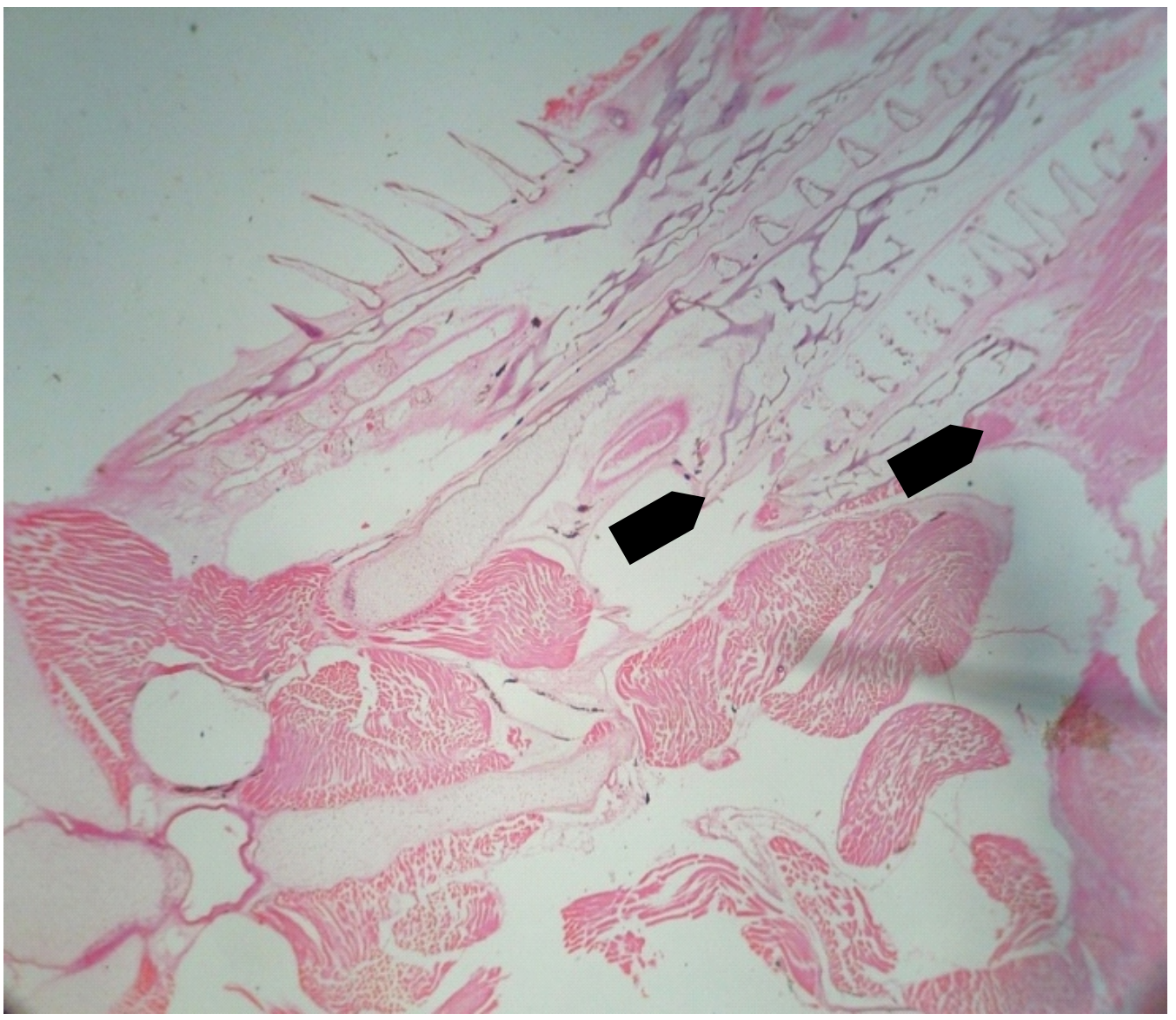

PLATE 6:Fish gills with inflammation.

Fish Gill at $0.04 \mathrm{ml} / \mathrm{L}$ with inflamtion ( $\longrightarrow$ ). Magnification x10

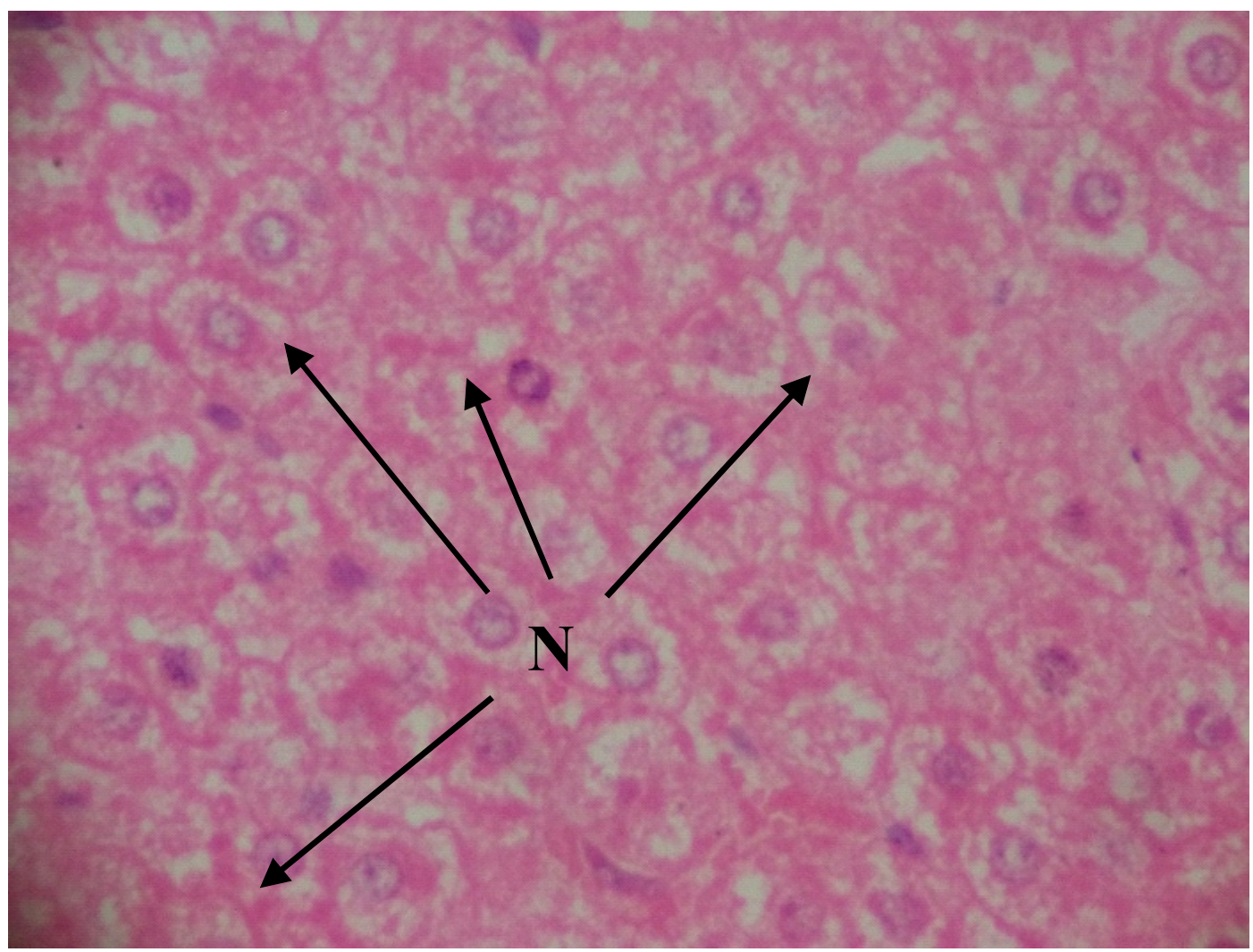

PLATE 7: Normal fish liverwith normal nuclei of the hepatocytes.

Control $0.00 \mathrm{ml} / \mathrm{L}$, the nuclei $(\mathrm{N})$ of the hepatocytes are clearly revealed and the chain like arrangement of the hepatocytes are revealed in the photomicrograph. Magnification x400 
22 | Sublethal effects of the Water -Soluble Fractions of Virgin Diesel Oil on some Physiological ...

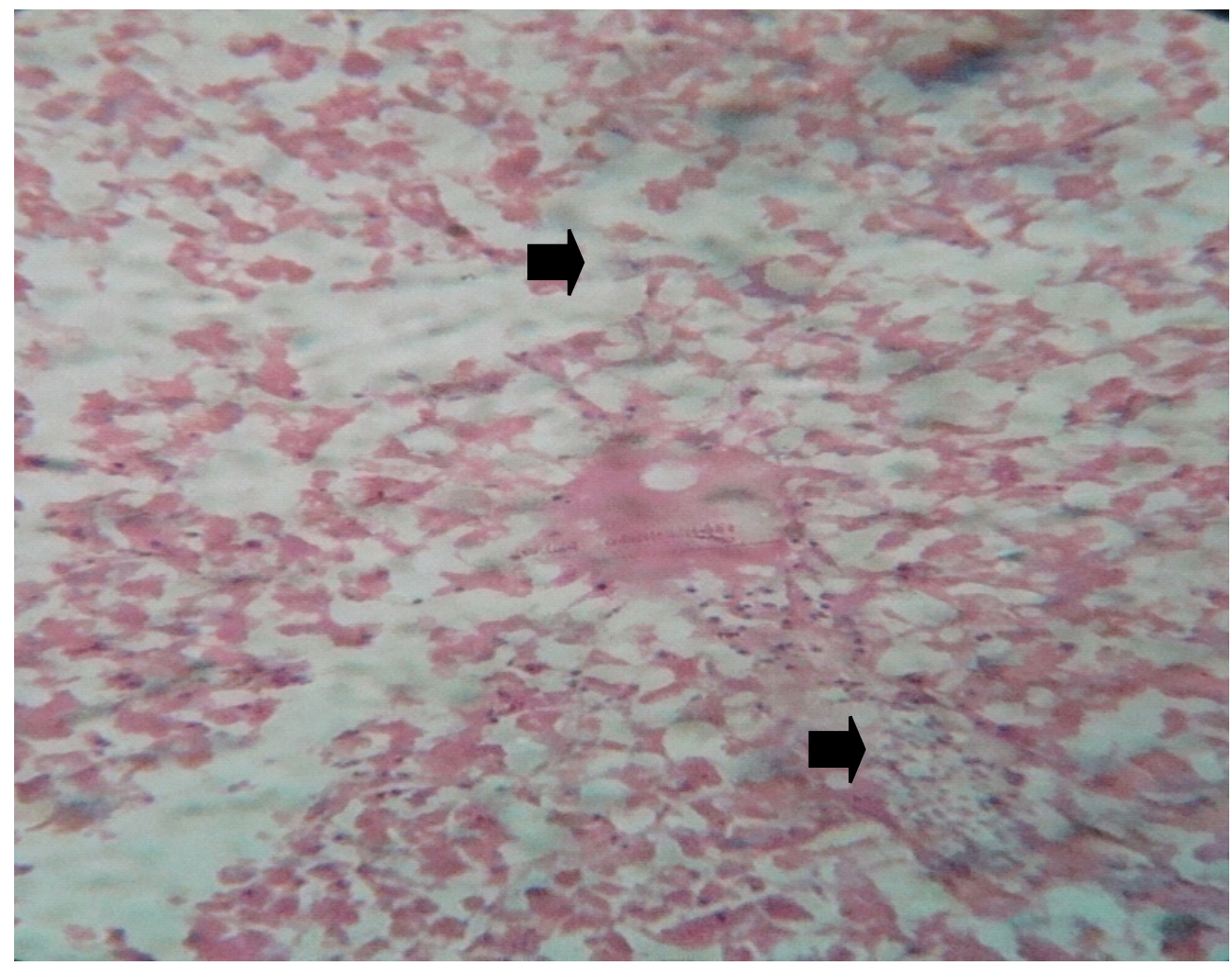

PLATE 8: Fish liver with necrosis and aggregation of polymorhonuclear cells.

Concentration $0.58 \mathrm{ml} / \mathrm{L}$ having severe necrosis of the hepatocytes and there is total disappearance of septa of collagenous supporting tissue that form boundaries between adjacent lobules.There is aggregation of polymorphonuclear cells around the portal vein which is indicative of infection.(믈 a a result of severe necrosis.Magnification $\times 100$

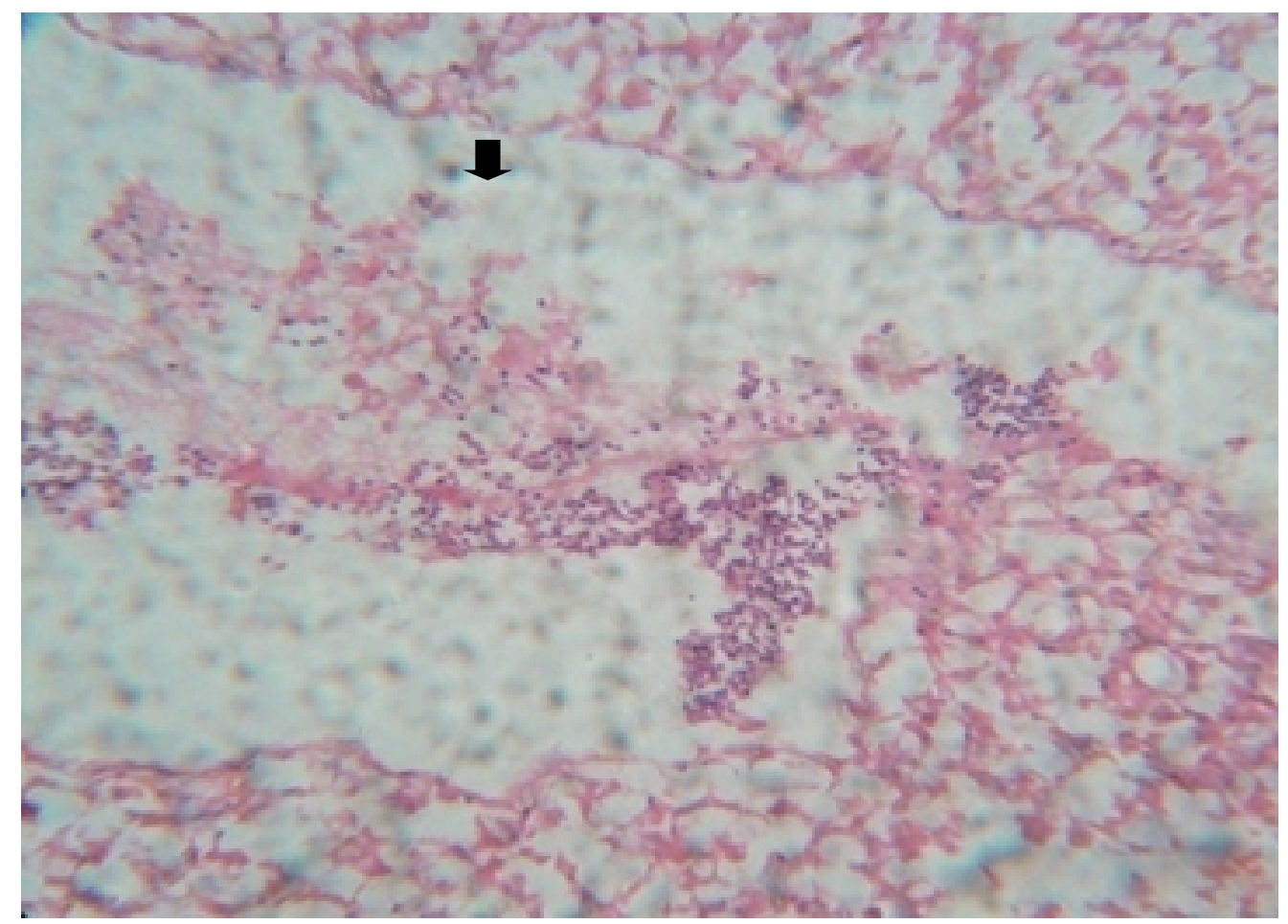

PLATE 9: Fish Liver with necrosis of the hepatocytes and disappearance of septa.

Consentration $0.29 \mathrm{ml} / \mathrm{L}$ having s evere necrosis of the hepatocytes and distortion of the lobular arrangement of the parenchymal cells of the liver, there is total disappearance of septa of collagenous supporting tissue that form boundaries between adjacent lobules.There is aggregation of polymorphonuclear cells which is indicative of infection ( $\vec{l}$ ).

Magnification x 100 


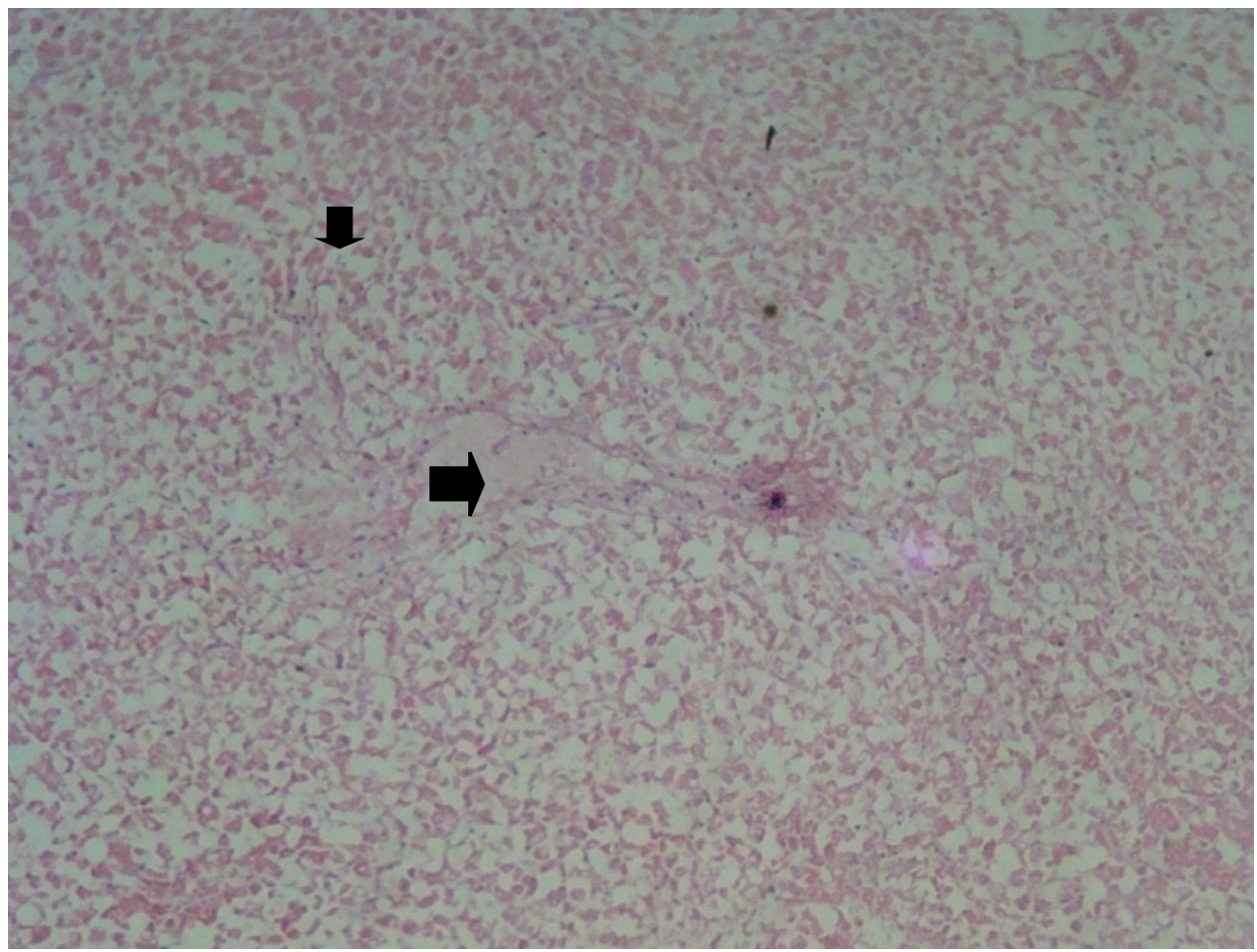

PLATE 10: Fish liver necrosis and portal vein congestion.

Concentration $0.14 \mathrm{ml} / \mathrm{L}$ with severe necrosis and complete distortion of the hepatocytes chain like arrangement.There is total disappearance of septa of collagenous supporting tissue that form boundaries between adjacent lobules. The portal vein

(a) is congested. Magnification x 100

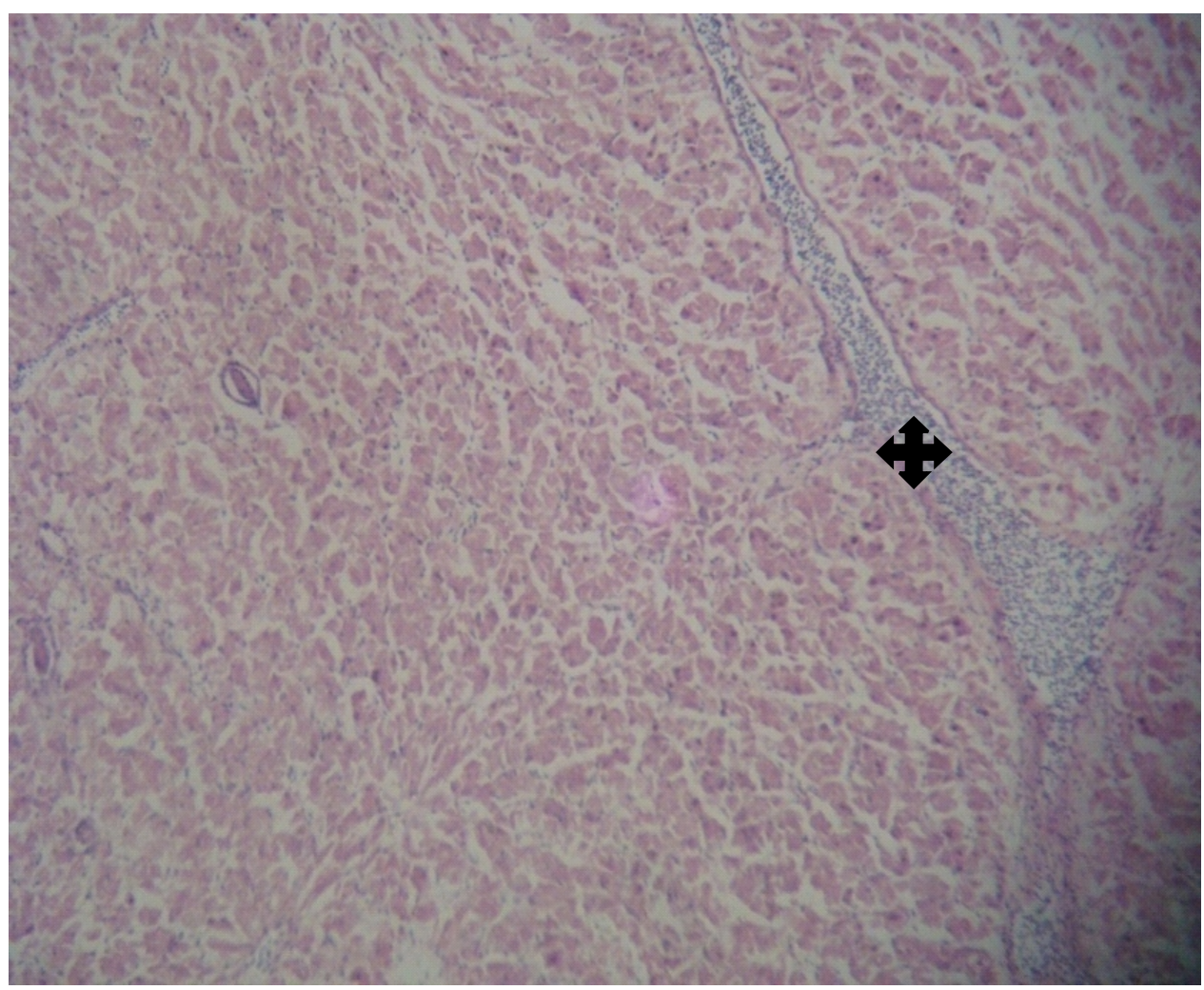

PLATE 11 : Fish liver necrosis and disappearance of septa.

Consentration $0.07 \mathrm{ml} / \mathrm{L}$ having severe necrosis of the hepatocytes and distortion of the lobular arrangement of the parenchymal cells of the liver, there is total disappearance of septa of collagenous supporting tissue that form boundaries between adjacent lobules. There is aggregation of polymorphonuclear cells which is indicative of infection $(\$)$. Magnification $\mathrm{x}$ 
24 | Sublethal effects of the Water -Soluble Fractions of Virgin Diesel Oil on some Physiological ...

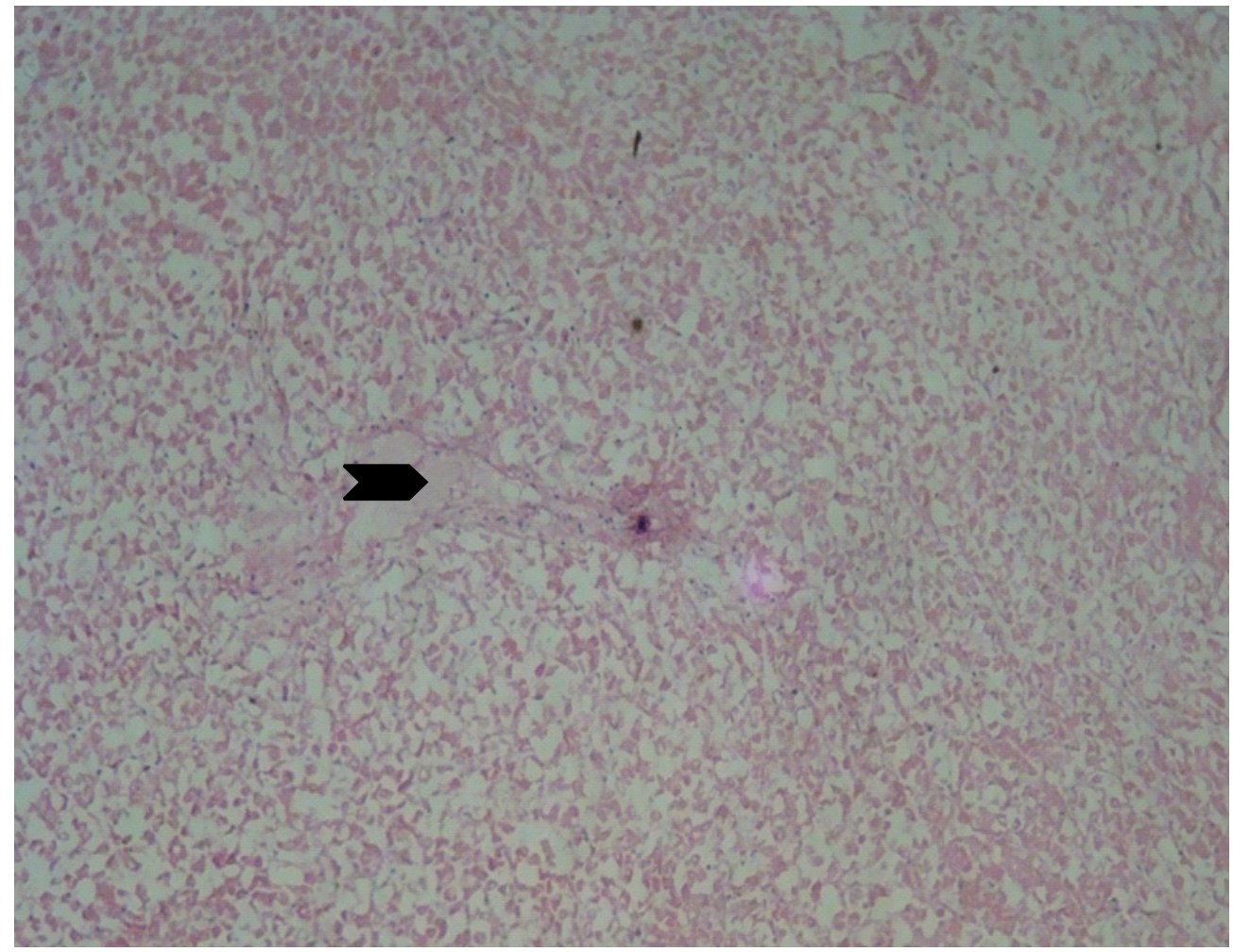

PLATE 12 : Fish Liver necrosis of the hepatocytes. Contration $0.04 \mathrm{ml} / \mathrm{L}$ with necrosis of the hepatocytes and distortion of the lobular arrangement of the parenchymal cells of the liver, there is total disappearance of septa of collagenous supporting tissue that form boundaries between adjacent lobules. The portal vein

( $\mathbf{D}$ ) is congested. Magnification x100

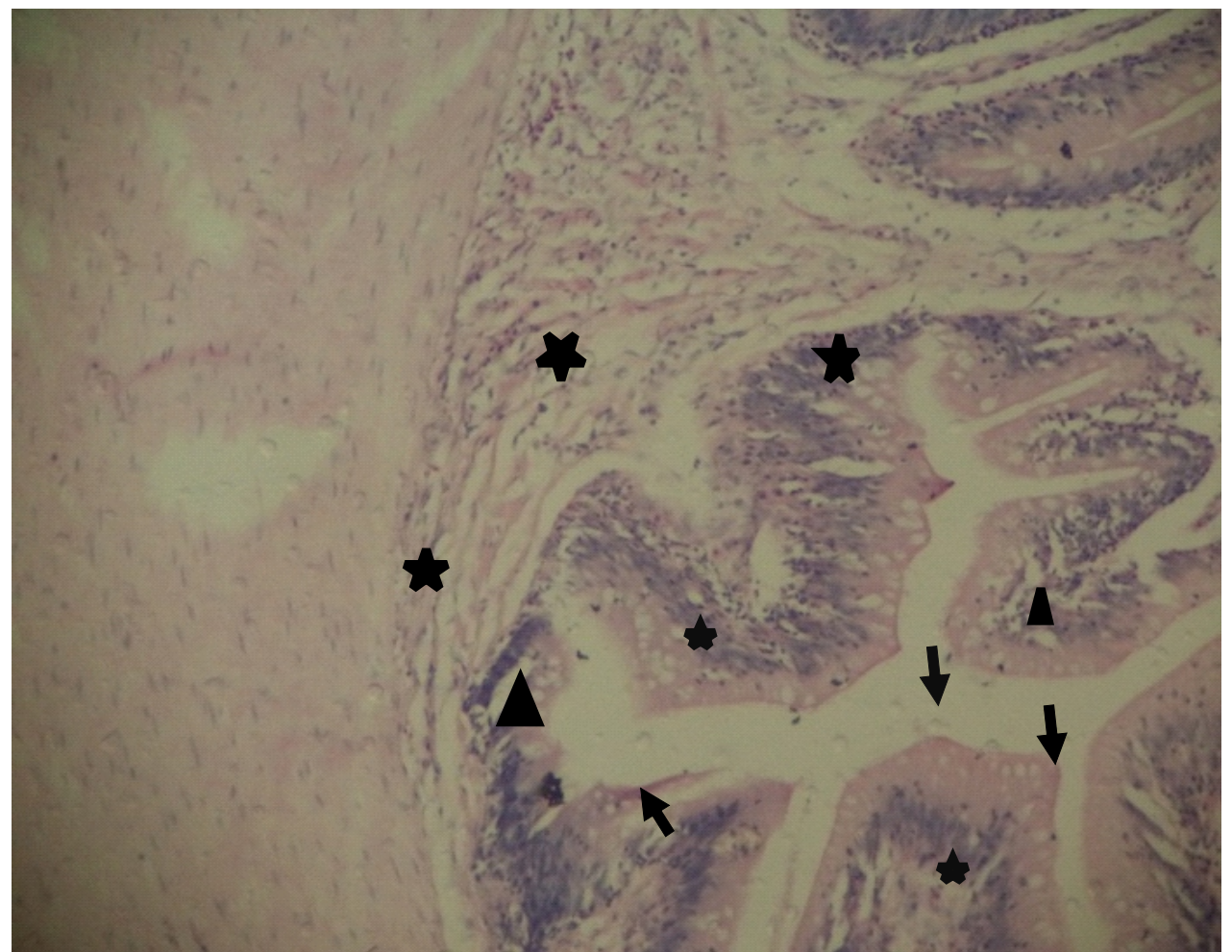

PLATE 13: Normal fish Intestine

Control $0.00 \mathrm{ml} / \mathrm{L}$ the villi are intact. There is no sloughing of the epithelial lining of the villi $(\downarrow)$. The goblet cells $(\downarrow)$ ) are in abundance as indicated by the black arrows. The muscular wall $(\boldsymbol{\Lambda})$ and the submucosa ( $\boldsymbol{\Lambda}$ ) are all normal. Magnification x100 


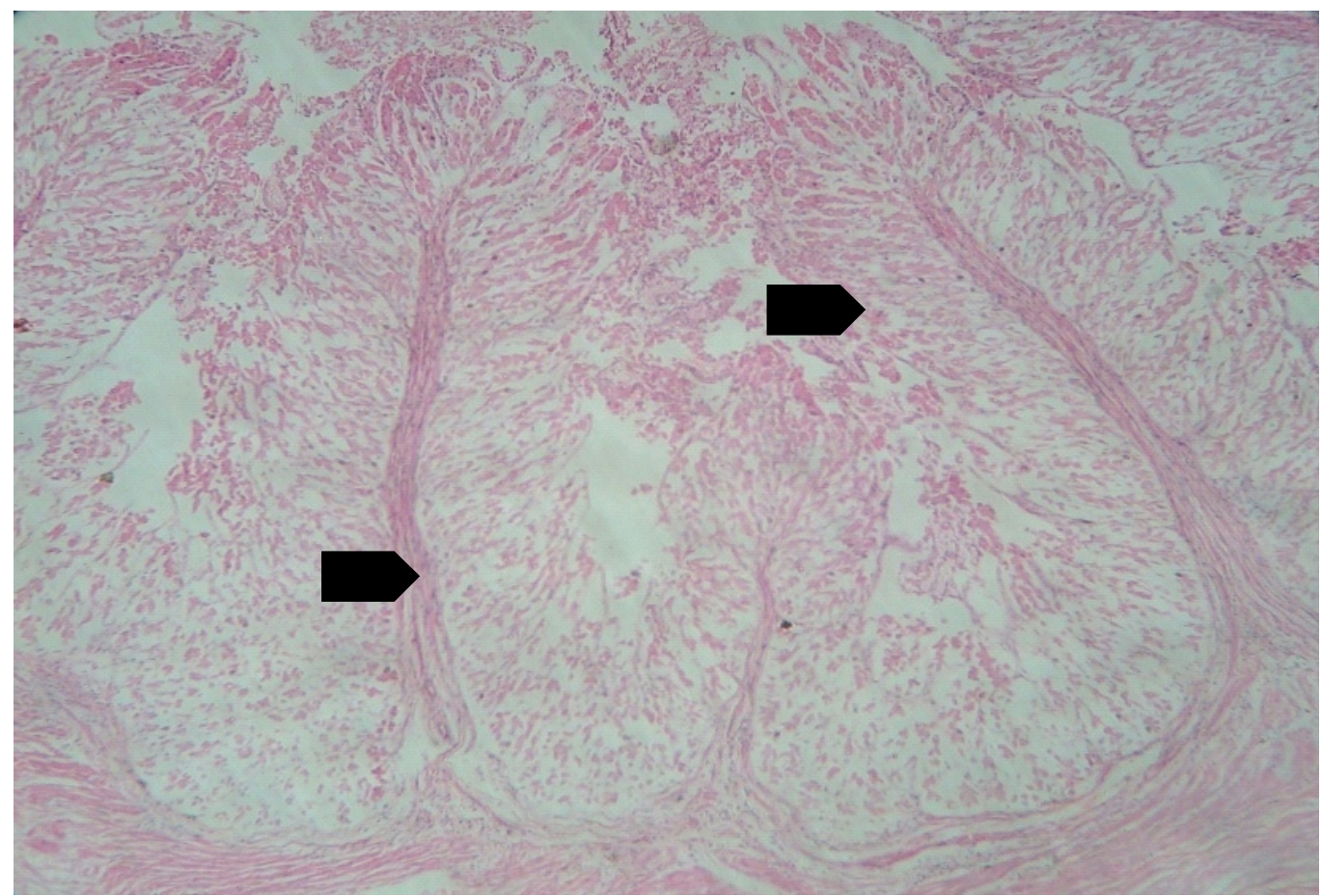

PLATE 14: Necrosis of the Intestine.

Concentration $0.59 \mathrm{ml} / \mathrm{L}$ having severe necrosis of the intestinal villi with total absence of the epithelia due to severe sloughing as indicated by the arrow ( $(\square)$. Magnification x10

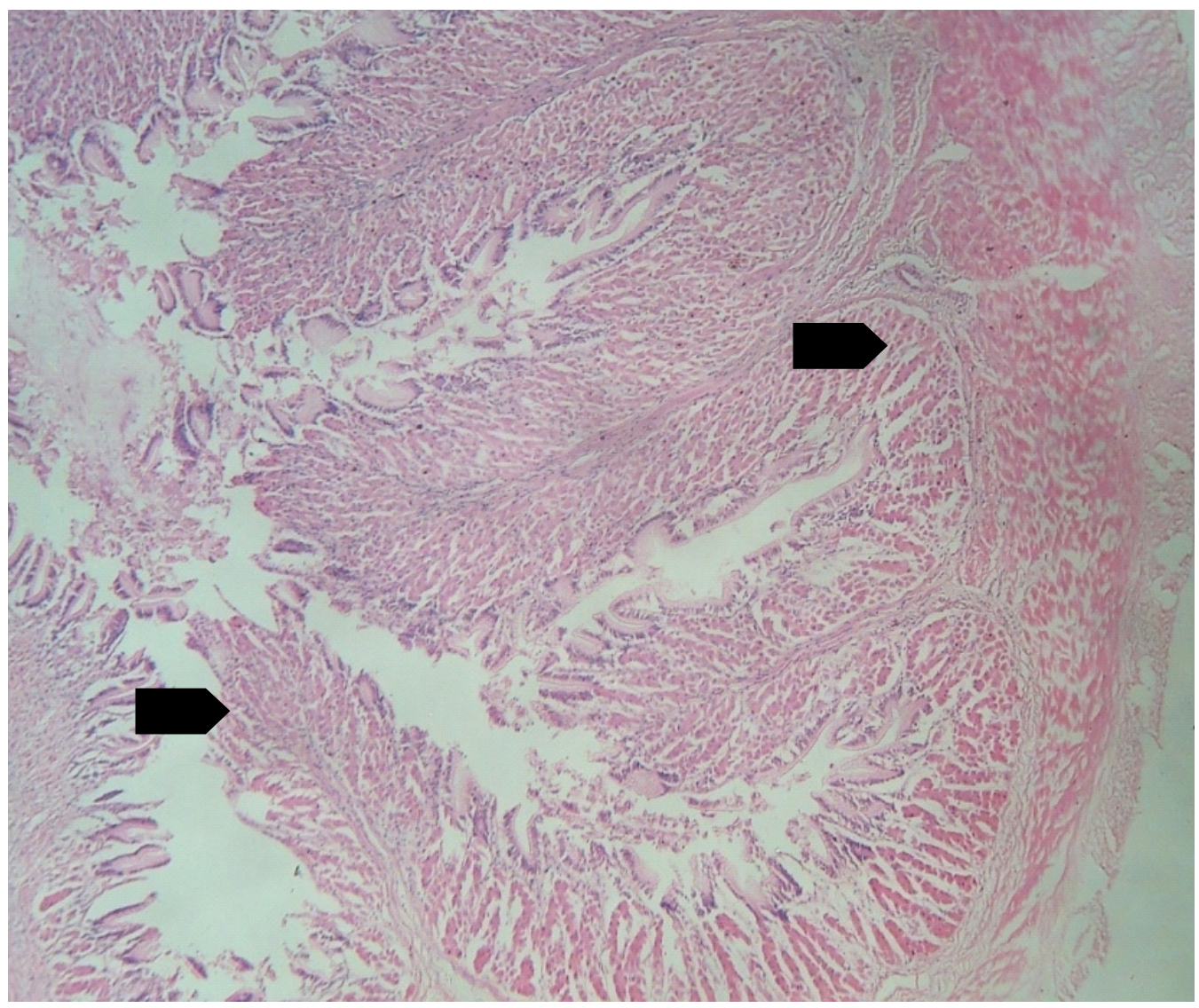

PLATE 15: sloughing of the Intestinal mucosa.

Concentration $0.29 \mathrm{ml} / \mathrm{L}$ with sloughing of the intestinal mucosa asindicated by the arrow Magnification x10 
26 | Sublethal effects of the Water -Soluble Fractions of Virgin Diesel Oil on some Physiological ...

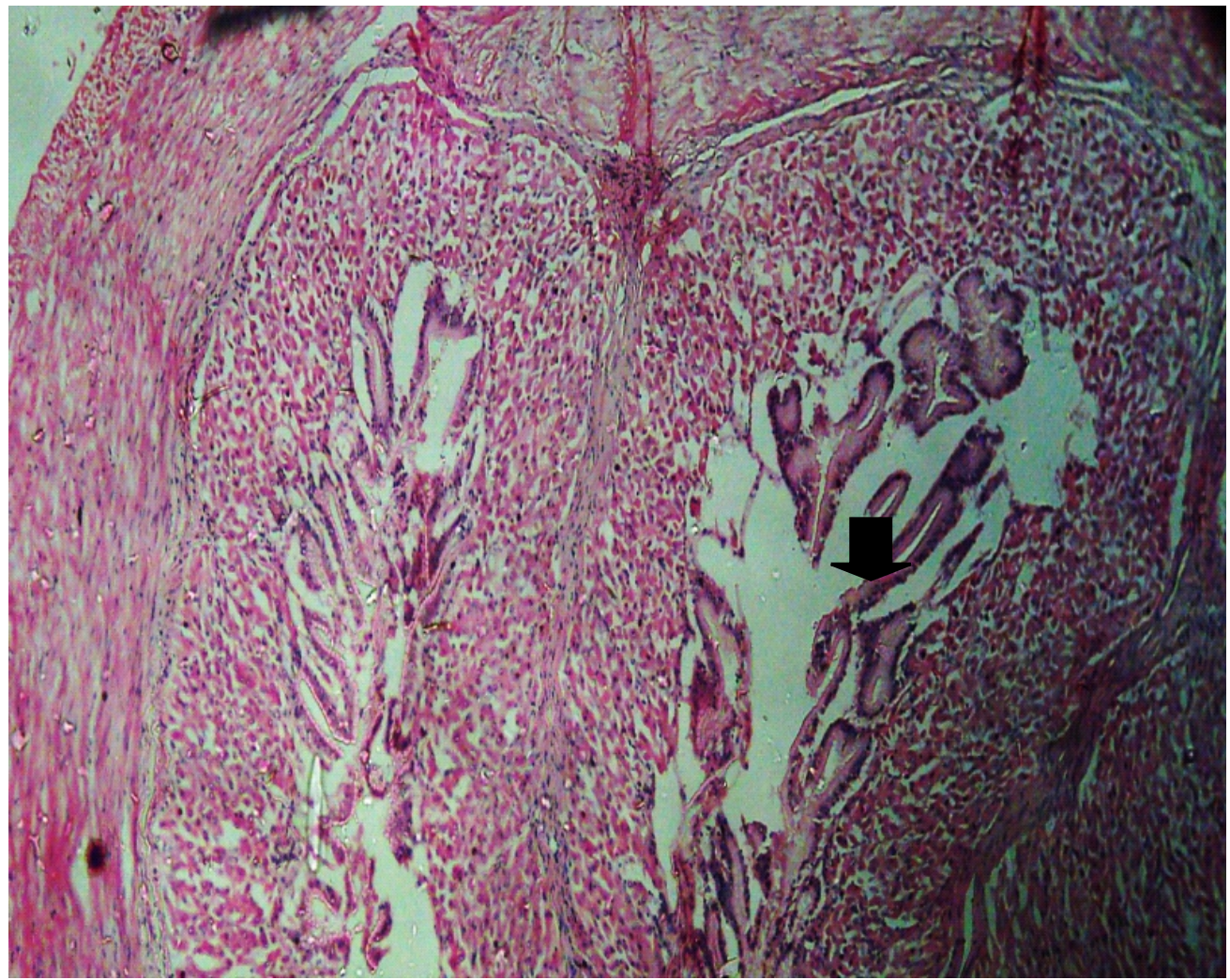

PLATE 16: Sloughing of the Intestinal epithelia.

Concentration $0.14 \mathrm{ml} / \mathrm{L}$ with sloughing of the intestinal epithelia as indicated by the arrow ( $)$. Magnification x10

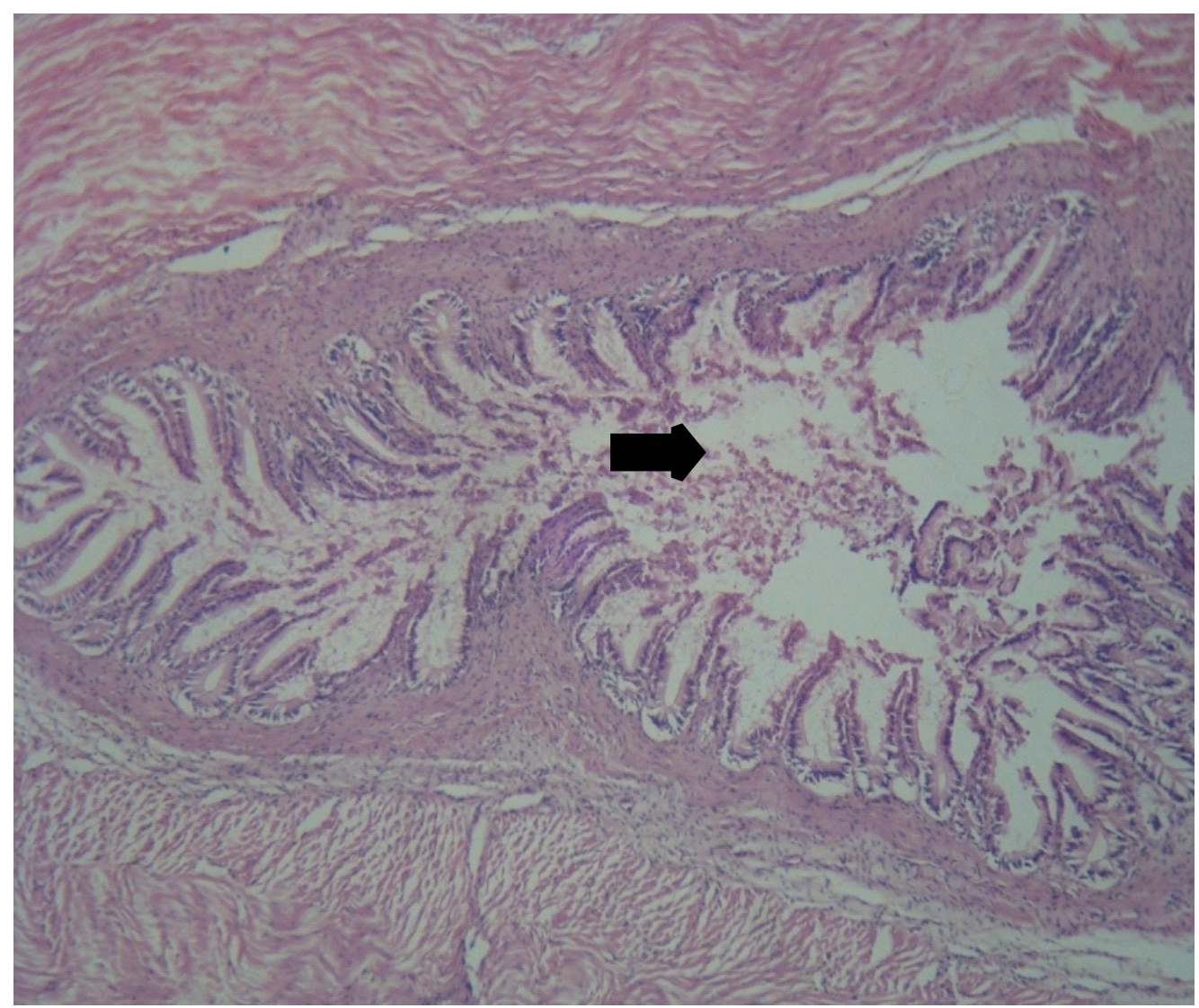

PLATE 17:Sloughing of the intestinal villi.

Concentration $0.07 \mathrm{ml} / \mathrm{L}$ with sloughing of the intestinal villii $\Rightarrow$ of the small intestine. Magnification x10 


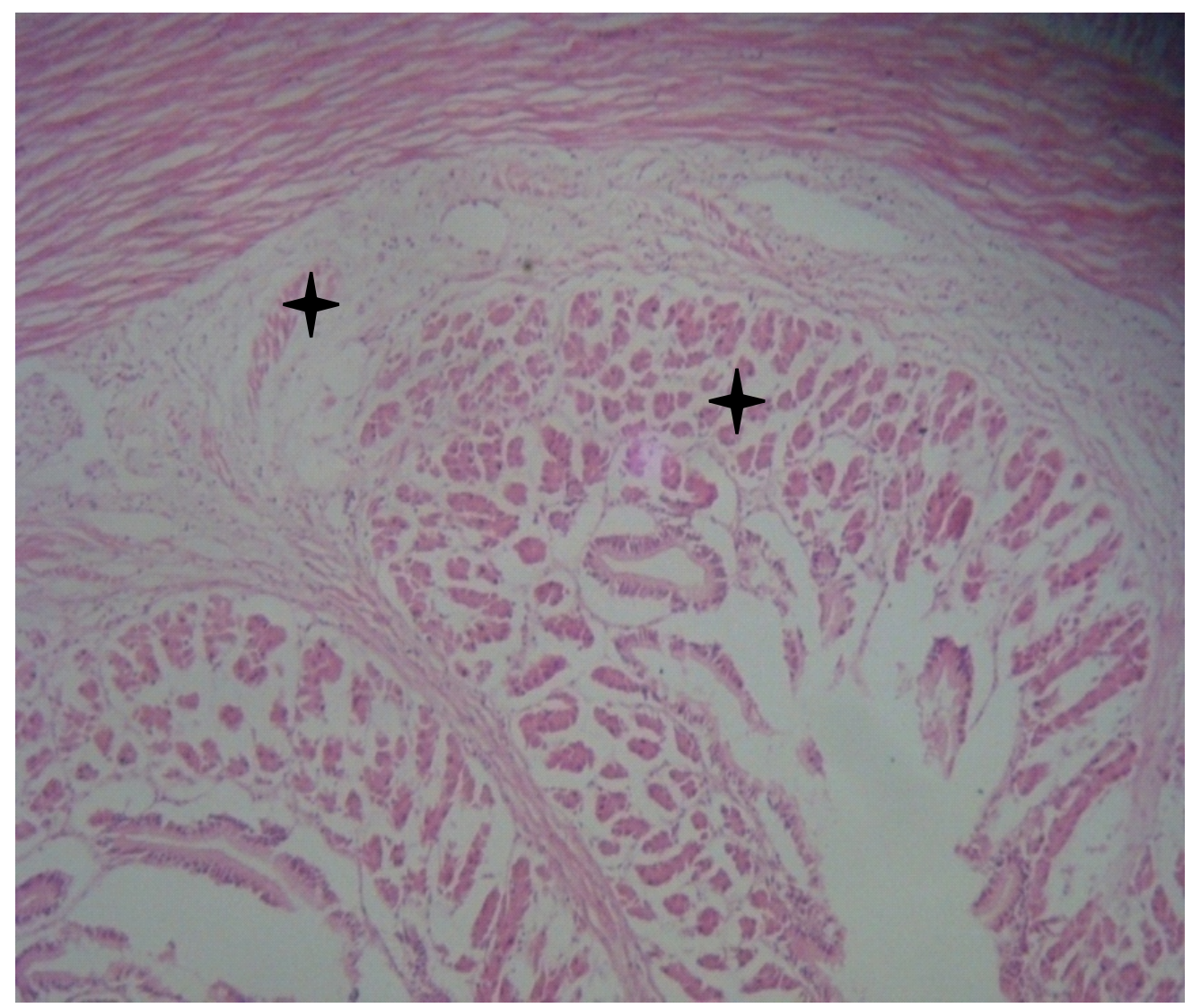

PLATE 18:Sloughing of the Intestinal villi.

Concentration $0.04 \mathrm{ml} / \mathrm{L}$ with sloughing of the intestinal villi of the small intestine $(t)$. Magnification x10

\section{Discussion}

Despite the importance of water temperature in influencing environmental factors for fish growth, metabolism and water dynamics by El-nemaki, Ali, Zeinhom and Radwan (2008) but this study ranges between 23 $-39^{\circ} \mathrm{C}-25.67^{\circ} \mathrm{C}$ with concentration $0.58 \mathrm{ml} / \mathrm{L}$ having the highest temperature mean value on the row, yet $(\mathrm{P}>0.05)$ shows there was no significant difference between the means of the various concentration of the water - soluble fraction of virgin diesel oil in the experimental plastic bowl and the control, therefore, the water-soluble fraction of virgin diesel oil had no influence oil temperature, but has effect on the organisms.

The mean values of $\mathrm{pH}$ for concentration $0.58 \mathrm{ml} / \mathrm{L}, 0.29 \mathrm{ml} / \mathrm{L}, 0.14 \mathrm{ml} / \mathrm{L}$ and $0.07 \mathrm{ml} / \mathrm{L}$ are significantly related $(\mathrm{P}<0.05)$ and also related with the value under concentration 0.04 $\mathrm{ml} / \mathrm{L}$. the value of concentration $0.58 \mathrm{ml} / \mathrm{L}, 0.29$ $\mathrm{ml} / \mathrm{L}, 0.14 \mathrm{ml} / \mathrm{L}$ and $0.07 \mathrm{ml} / \mathrm{L}$ are significant and also the same with the mean value under concentration $0.04 \mathrm{ml} / \mathrm{L}$. There are not high significant difference through all the mean values of the $\mathrm{pH}$, these can also be compared to
(Table 1) with $\mathrm{pH}$ range of $3.00-7.25$ which the $\mathrm{pH}$ can still support lives and table $2 \mathrm{pH}$ range was also still within $5.13-6.27$ can also support survival of tropical fish species Boyd (1990) and Lagler (1952). The maintenance of the range above could be attributed to changing the experimental media and replacement after three (3) days to avoid accumulation of feacal materials and feeding.

Dissolved oxygen (DO) level mean value from concentration $0.07 \mathrm{ml} / \mathrm{L}$ and $0.04 \mathrm{ml} / \mathrm{L}$, when you look at the mean value of control $0.00 \mathrm{ml} / \mathrm{L}$ were significantly related $(\mathrm{P}<0.05)$ with value for concentration $0.58 \mathrm{ml} / \mathrm{L}$ and $0.14 \mathrm{ml} / \mathrm{L}$ concentration to be significantly the same as concentration $0.58 \mathrm{ml} / \mathrm{L}, 0.29 \mathrm{ml} / \mathrm{L}$ and $0.14 \mathrm{ml} / \mathrm{L}$, this is due to increase in concentration and it also confirmed the report of Nwabueze and Agbogidi (2010) and Rodrigues et al.,(2010) with increasing hydro carbon content of water.

Electricity conductivity of the mean value on the row, the control $0.00 \mathrm{ml} / \mathrm{L}$ was not significant when $(\mathrm{P}>0.05)$ from the value of concentration $0.58 \mathrm{ml} / \mathrm{L}, 0.29 \mathrm{ml} / \mathrm{L}, 0.14 \mathrm{ml} / \mathrm{L}$ and $0.07 \mathrm{ml} / \mathrm{L}$ but related when $(\mathrm{P}<0.05)$ with 
the value for concentration $0.04 \mathrm{ml} / \mathrm{L}$. the mean value for $0.58 \mathrm{ml} / \mathrm{L}, 0.29 \mathrm{ml} / \mathrm{L}$ and $0.14 \mathrm{ml} / \mathrm{L}$ and also with control value of $0.00 \mathrm{ml} / \mathrm{L}, 0.07 \mathrm{ml} / \mathrm{L}$ and $0.04 \mathrm{ml} / \mathrm{L}$. The value for concentration 0.07 $\mathrm{ml} / \mathrm{L}$ was not significant $(\mathrm{P}>0.05)$ from the control mean value $0.00 \mathrm{ml} / \mathrm{L}$, concentration $0.58 \mathrm{ml} / \mathrm{L}$ and $0.14 \mathrm{ml} / \mathrm{L}$ but significant when $(\mathrm{P}<0.05)$ with the mean value for concentration $0.04 \mathrm{ml} / \mathrm{L}$. Electrical conductivity increases with increase in concentrations support Okogwu et al.,(2015). The electrical conductivity value for concentration $0.58 \mathrm{ml} / \mathrm{L}$ was the highest followed by the value for concentration 0.29 $\mathrm{ml} / \mathrm{L}$, the decrease continue to concentration $0.04 \mathrm{ml} / \mathrm{L}$. The decrease continues based on the highest concentration to the lowest concentration as recorded by Okogwu et al., (2015) that means conductivity increase with increase in the concentration of the toxicant. The value for control $0.00 \mathrm{ml} / \mathrm{L}$ was the lowest since no toxicant was added to it. Increase in substance increases electrical conductivity.

Total dissolved solid (TDS) mean value for the control $0.00 \mathrm{ml} / \mathrm{L}$ have significant different $(\mathrm{P}<0.05)$ also with value for concentration $0.04 \mathrm{ml} / \mathrm{L}$ and the value for concentration $0.07 \mathrm{ml} / \mathrm{L}$. The value for concentration $0.58 \mathrm{ml} / \mathrm{L}$ and $0.29 \mathrm{ml} / \mathrm{L}$ are significantly the same, but not related $(\mathrm{P}>0.05)$ with control $0.00 \mathrm{ml} / \mathrm{L}$, concentration $0.07 \mathrm{ml} / \mathrm{L}$ and $0.04 \mathrm{ml} / \mathrm{L}$ but related with the value for concentration $0.14 \mathrm{ml} / \mathrm{L}$. The control $0.00 \mathrm{ml} / \mathrm{L}$ without treatment was having the lowest mean value and concentration $0.58 \mathrm{ml} / \mathrm{L}$ was having the highest mean value followed by concentration $0.29 \mathrm{ml} / \mathrm{L}$ and continues decrease as the concentration decrease. This result agrees with that of Okogwu et al., (2015) that TDS increases with increase in concentration of the toxicant.

The growth performance and feed utilization of Clarias gariepinus juveniles during the period of exposure for ten (10) weeks to the sublethal concentration of virgin diesel oil shows the mean value on (Table 2). The control had weight gain of $0.5(21 \%)$, total length gain $4.2(34.83 \%)$ and standard length gain 1.5 ( $14.56 \%$ ) concentration $0.58 \mathrm{ml} / \mathrm{L}$ weight gain of $0.23(9.75 \%)$, total length of $1.6(14.17 \%)$ and 3.6 standard length gain (37.82\%), concentration $0.29 \mathrm{ml} / \mathrm{L}$ had weight gain of 0.06 $(2.46 \%)$, total length gain of $0.99(7.76 \%)$ and standard length gain of $2(20.20 \%)$ gain.
Concentration $0.14 \mathrm{ml} / \mathrm{L}$ had weight gain of $0.46(20.09 \%)$, total gain in lenght 1.51 $(9.04 \%)$, standard length gain. Concentration $0.07 \mathrm{ml} / \mathrm{L}$ had a weight increase of 0.53 $(23.14 \%)$, total length gain of $3.76(30.62 \%)$ and concentration $0.04 \mathrm{ml} / \mathrm{L}$ had gain of 0.51 (22.27\%), total length gain of $3.79(29.82 \%)$ and standard length gain of $3.79(29.82 \%)$ and standard length gain of $2.55(24.78 \%)$.

The growth rates in the water - soluble fractions of virgin diesel oil in the treatment container where significantly lower than rates of the untreated Clarias gariepinus juveniles in the control. The ten (10) weeks exposure period, of water-soluble fractions of virgin diesel oil concentration of $0.58 \mathrm{ml} / \mathrm{L}, 0.29$ and $0.14 \mathrm{ml} / \mathrm{L}$, the growth rates remained at the same reduced level during the tenth week of exposure. The following people (Abdel-Tawab and Wafeek (2008) observed using oreochromis niloticus that fish growth and survival reduced when exposed to cadmium. They further reported that fish survival decreased significantly with increasing cadmium concentration in the same way as growth and feed utilization were affected with increasing sublethal concentrations of virgin diesel oil in this research work. Onwurah et al., (2013) and Nwani et al., (2015) also reported that the threat of oil pollution to fish and invertebrates are seldom just from acutely toxic concentration that resulted in immediate fish and zoo plankton kills, but also from the more subtle effects of heavily weathered oil to sensitive life stages.

Nigeria is a developing country, most developing countries normally have the problem of oil spillage and this normally pose a serious danger to the soil and aquatic life. This study with the effects that were observed, it will be good that the relevant bodies or authorities responsible for laws, policies and enforcement measures do well to monitor the production areas and marketers country wide.

\section{Gills}

Epithehlial hyperplasia are some of the observable effects of toxicant either of organic or inorganic toxicants. These effects were equally observed in this study reported by Mallat, (1985) and Roberts, (2001) that in order to increase the epithehlial area for diffusion as well as reduce contaminant absorption into the blood, epithehlial hyperplasia are considered as 
a protection response to toxins, Irritants and environmental stressors. Roberts, (2001) observed that epithehlial lifting and fusion of the fish gills exposed to pollutant as also observed in plate 3 above, will result in oxygen intake shortage. The aneurism observed on the other hand, still represents a lesion which was also observed on plate 4 result from the rapture of pillar cells, and thus corresponds to the deleterious effect of xenobiobiotics on branchial tissue by Martinez et al, (2004) this study also agree to it. The moderate areas of lesion, necrosis and inflammation in the gills as observed also support Omitoyin et al., (1999) who used herbicides. Other investigations Misra, et al., (1985) and Beriberi et al. (2002),support the fact that damages to the gills had wider implications and it could lead to asphyxia that is "a condition in which an extreme decrease in the concentration of oxygen in the body leads to loss of consciousness or death of the fish over a period of time.

\section{Liver}

The histological alterations observed in this study indicates that fish liver responds to water-soluble fraction of virgin diesel oil. Fish liver is an organ that performs various functions associated with the metabolism of xenobiotics substance Jimenez and stegemen, (1990). This very study showed, necrosis of the hepatocytes, congestion of the portal vein, degeneration or distortion of the lobular arrangement of the liver cells and aggregation of polymorphonuclear cells which agree with the work of Preeti et al., (2011) using water soluble fractions of diesel fuel to induced histological alterations in the liver of Channa punctatus; it was further observed the disappearance of the septa; that is the collagenous supporting tissues that form boundaries between adjacent lobules. Since the liver is a strong organ, the distortion or disappearance of polymorphonuclear (neutrophils) of some portions of the liver tissue that were observed probably resulted from the excessive work required by the fish to get rid of the toxicant from it's body during the process of detoxification, similar to the observation of Rahman et al .,(2002). The inability of the fish to regenerate new liver cells faster may also had led to all this damages.

\section{Intestine}

The necrotic changes in the intestinal mucosa, the atrophy in the musculans and inflammatory cells agrees and support the work of Bhatnagar et al., (2007) which was observed in T.zilii and S. valgaris from the lake Qarum. Epithehlial degeneration, the inflammatory cells infiltration in the submucosa as well as submucosal was seen in the intestine of tilapia fish exposed to carbofura, Soufy et al., (2007) the pathological alterations in the intestine of the studied fish are in agreement with those observed by many researchers about the effects of different toxicant on fish intestine Hanna et al.,(2005) and Cengiz et al., (2006), sloughing, that is eroding or peeling away of the intestinal villi was also observed.Intestine are not easily affected but when they are affected it means the pollutant are toxic.

\section{Conclusion}

In conlusion the observations on clarias gariepinus in this study based on the parameters used; it could be concluded that the species are relatively more tolerant to low level of watersoluble fraction of virgin diesel oil and probably develop resistance with time to be able to cope with some of it's physiological activities. The histopathological alteration in the tissue and organs such as the gills, liver and intestine of the C. gariepinus exposed in the varying concentrations of the water-soluble fraction of virgin diesel oil in this study showed the level of toxicity even for small quantities if exposed for longer time could be dangerous.

The unregulated siting of filling station for diesel, illegal transportation of fuel and other petroleum products should be discouraged, since linkages or mishandling of filling stations products or could pose a threat to aquatic environment.

\section{Recommendation}

The following recommendations are based on the results recorded in this research;

The environmental impact assessments (EIA) should be able to put in place measures that will determine the level of soil contamination and water bodies before projects are sited for oil project owners is very important, that will help to reduce soil and aquatic pollution.

However, since the C.garirepinus is an important aquaculture fish in Africa and developing country such as Nigeria, there is 
need for researchers to follow prevention technique from developed nations where environmental monitoring agencies are more effective and environmental laws and legislations are strictly adhered to.

\section{Acknowlegements}

Authors are grateful to God Almighty, the Zoology Department laboratory attendants, of the Faculty of Natural and Applied Sciences, Keffi, Nasarawa State and the National Veterinary Research Institute Vom (NVRI) Central Diagonostic laboratory histology unit for assisting in the histology aspect.

\section{Reference}

Abdel-Tawwab, M., and Wafeek, M., (2008). Response of Nile Tilapia O.niloticus to Environmental cadmium toxicity during organic selenium supplementation. $8^{\text {th }}$ international symposium on Tilapia in Aquaculture volume,(1) pp 414-431

Afolabi, O. A., Adeyemi, S.A. and Imevebore, A. M. A. (1985). Studies on toxicity of some Nigerian crude oil to some aquatic. Proceedings of the International Seminar on petroleum industry and Nigerian environment NNPC, 269-272

Anderson, J.W., Neff, J.M., Cox, B.A., Tatem, H.E., Hightower, G.M. (1974). Characteristics of dispersions and water soluble extracts of crude and refined oils and their toxicity to estuarine crustaceans ad fish from Cross River Estuary, Nigeria. West African journal of Applied Ecology, 3:91-97.

Avwioro, O.G (2011). Staining reactions of microwave processed tissues compared with conventional paraffin wax processed tissues. European Journal of Experimental Biology: 1 (1): 57-62

Barbieri, E. (2002). Effect of 2,4-D herbicide (2,4dichlorophenoxyacetic acid) an oxygen consumption and ammonium excertion of juveniles of Geophagus brasillenisis (Quoy \& Gaimard, 1824) (Osteichthyes, Cichlidae). Ecotoxicology 18: 55-60

Bilberg K, Malte H, Wang T, Baatrup E (2010b) Silver nanoparticles and silver nitrate cause respiratory stress in Eurasian perch (perca fluviatilis). Aquatic toxicolology 96: 159
Bols N.C, Brubacher J.I.,Ganassin R.C, Lee LEG (2001) Ecotoxicology and innate immunity fish. Development Comparative Immunology 25(8-9): 853-873

Boyd, C.E (1990)Water quality in ponds for aquaculture .Agriculture experiment station, Auburn University, Alabama, Usa,Pp 97-98.

Bhatnagar, C, M. Bhatnagar and B. Rgar,

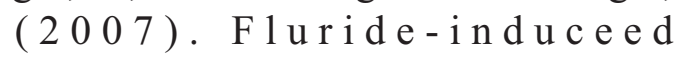
histopathological changes in gill, kidney and intestine of freshwater teleost, labeo rohita. Res. Rep. Fluride 40:55-61.

Cengiz E. and E. Unlu, (2006). Sublethal effects of commercial deltamethrin on the structure of the gill, liver and gut tissues of osquitofish, gambusia affinis: A microscopic study. Environmental. Toxicolology. Pharmacolology., 21:246-253.

Choji.T.P.P., Ngokere, A.A., Ogenyi, S.I., and Kumbish, P.R. (2015). Histoarchitechtural Evaluation of Conventional Versus Two Rapid Microwave Processing Techniques. British Biotechnology Journal 8(3):119.

Connell, S.D, Koning, D.J and Cather, S.M, (1999) Revision to the stratigraphic nomenclature of the santa fe group, northestern Albuquerrque basin, New Mexico, in Pazzalhia, F.S and Lucas, S.G, eds., Albuquerque geology. New mexico Geological Society, 50 ${ }^{\text {th }}$ Field conference Guidebook pp 338 - 354.

Dede, E.B; and Kaglo H.D. (2001). Aquatoxicological effects of water-soluble fractions of diesel feul on O.niloticus fingerlings. journal Application science. Environmental. management. pp 92-97

El-nemaki, F.A., Ali, N.A., Zeinhom, M.M and Radwan, O.A., (2008) Impact of different water resources on the ecological parameters and the quality of Tilapia production at EL-ABBASSA fish farm Egypt $8^{\text {th }}$ international symposia on Tilapia in Aquaculture vol 1, pp 4 490-512.

Faberge J, Luoma S.N, Tyler C.R, Galloway T.S, Lead J.R (2011) Silver nanoparticles: behavior and effects in the aquatic environment. Environ Int. 
37:517-531

FAO (2016). The state of world fisheries and Aquatic 2016. Contributing to Food security and Nutrition

for A1l. Fisheries and Aquaculture Department, Food and Agriculture Organization of the United Nations. Rome. 200 . Avai $1 \mathrm{ab} 1 \mathrm{e}$ on $1 \mathrm{ine}$ at www.fao.org/3/ai5555e.pdf.

Handy RD, Al Bairuty G, Al-Jubory A, Ramadon CS, Boyle D, Shaw B.J Henry T.B (2011) Effects of manufactured nanomaterials on fishes. A target organ and body systems physiology approach. Journal of fish Biology 79: 821-853.

Hanna, M., I. Shaheed and N. Elias, (2005). A contribution on chromium and lead toxicity in cultured Orechromis niloticus. Egypt Journal. Aquatic. Biology. Fish., 9:177-209.

Jimenez, B.D., Stegeman, J.J., (1990). Detoxification enzymes as indicators of environmental stress on fish. In: Adams, S.M. (Ed), Biological Indicators of stress in fish. Bathesda, America fisheries society, volume. 8, pp. 67-79 (Chapter 6).

Kahru A, Savolainen K (2010) Potential hazard of nanoparticles: from properties to biological and environmental effects. Toxicology 269:89-91

Khabbazi M, Harsij M, Hedayati SAA, Gerami MH, Ghafari-Farsani H (2014a) Histopathology of rainbow trout gills after exposure to copper. Iran J Ichthyol I(3): 191-196

Klaine S.J, Alvarez P.J.J, Batley G.E, Fernandes T.F, Handy R.D, Lyon D.Y, Mathondra S, Mcl aughlin M.J, Lead J.R (2008) Nanomaterials in the environment behavior , fate, bioavailability, and effects. Environmental Toxicology Chemistry 27(1825): 1851.

Lagler, K.F (1952). Freshwater fishery biology. W.M.C Brown Company Dubyqu.lowa pp 11-40

Mallatt, J. (1985). Fish gill structural changes induced by toxicants and other irritants: a statistical review. Cannodians.fish. aquacultural scieince. 42:630-648

Martinez, C.B.R., Nagae, M.Y., Zaia, C.T.B.V., Zaia, D.A.M.,( 2004$)$. Acute morphological and physiological effects of lead in the neotropical fish prochilodus lineatus, Braz. Journal. Biology, 64, 797-807

Mishra, A.k and Mohanty, B (2009). Chronic exposure to sublethal hexavalent chromium affect organ hispathology and serum cortisol profile of a toleost, Channa puntatus (Blotch) science. Total Environment 407;50 pp5031-5039.

Nwabueze, A.A. and agbogidi, O.M (2010). Impact of water Soluble Fractions of Crude Oil on Growth Perfromance of the catfish Heterobranchus bidorsalis. ARPN Journal of Agricultural and Biological Science, Vol. 5(1) 43-46, Asian Research Publishing Network (ARPN)

Nwani, C.D, Ekweueme, H.I, Ejere V.C, Onyeke C.C, Chukwuka C.O, Peace O.S, and Nwadinigwe O.A (2015). Physiological effects of paraquat in juvenile African catfish, clarias gariepinus (Burchel 1822). Journal of costal life medicine, volume (3) pp 3543.

Okogwu, O.I, Anionwu Q; Anoke D.C and Ugwuezi, P.O (2015); Behavioural, Haematological and Histopatholical changes in the African catfish clarias gariepinus exposed to 2, 4-Dichlorophenoxygacentric Acid (2, 4-D) pp 28-35.

Omitoyin, E. Ufodike, E.B.C and Keke. I.R. (1999). Tissue chemistry of Oreochromis niloticus exposed to subethal, concentrations of Gamalin 20 and Actellic 25 EC. Journal of Aquatic Sciences 7:33-78.

Onwurah, F.B.,Okejim,J and Ajie ,O.C (2013) Effects of crude oil on Tilapia live performance. Asian Journal Of Natural And Applied Sciences Vol, 2 No, 1 Pp1-6

Preeti H.K ,Saxenar R.M, Rathee N.S And Mamta J.(2011) Water Soluble Fractions Of Diesel Fuel Induced Histopathological Altrations In The Liver Of Channa Punctatus. Jurnal of Toxicological International (1) Pp 1416.

Pauluis, C.D.A (1979) Aquatic effluent discharged by oil refineries. In environmental Impact of refinery effluent. Report No 5/\&4, Concave, 
32 | Sublethal effects of the Water -Soluble Fractions of Virgin Diesel Oil on some Physiological ...

Den Haag, Nether Land pp 53-71

Rahman K.S.M, Rahman Thahira J, Lakshmanaperumalsamy P. Banat I.M (2002). Towards efficient crude Oil degradation by a mixed bacterial consortium. Bioresource Technology, 85(3), pp. 257-261.

Robberts R.J. (2001) - Fish Pathology, $3^{\text {rd }}$ edition - WB Saunders, London, $472 \mathrm{p}$.

Rodrigues R. V., K.C. Miranda Filho, E.P. Gusmao, C.B. Moreira, L.A. Romano \& L.A. Sampio.(2010). Deleterious effects of water-soluble fraction of petroleum, diesel and gasoline on marine pejerrey Odonteshes argentinensis larvae. Science of the Total Environment, 408: 2054-2059.

Soufy, H., Soliman. E. El-manakhly and A. Gaafa, (2007). Some biochemical and pathological investigations on monosex Tilapia following chronic exposure to carbon furan pesticides. Global veterinaria, 1:45-52

Solangi, M.A. and R.M Overtresst (1982) Histopathological changes in two estuarine fishes, Menidia benyllina (Cope) and trimectes maculates (Block and Sneider) exposed to Crude Oil and its water soluble fractions .Journal. Fish Diseases, 5:13-35.

Ugwu.L.L.C, Mgbenka, B.O., and Ugwuaka K.A (2010). Effects of industrial effluents and municipal wastes on aspects of water quality of Ogba River, Benin city, Nigeria. Journal of Aquatic sciences 23 (1), pp 1-12.

Wegwu, M.O. and Omeodu, S.I. (2010). Evaluation of selected Biochemical indices in Clarias gariepinus exposed to Aqeous Extract of Nigerian Crude Oil (Bonny Light). Journal of applied Environment Management 14 (1) 77-81. 